\title{
Undernutrition, infection and immune function
}

\author{
Philip C. Calder* and Alan A. Jackson \\ Institute of Human Nutrition, University of Southampton, Bassett Crescent East, \\ Southampton SO16 7PX, UK
}

\begin{abstract}
Undernutrition and infection are the major causes of morbidity and mortality in the developing world. These two problems are interrelated. Undernutrition compromises barrier function, allowing easier access by pathogens, and compromises immune function, decreasing the ability of the host to eliminate pathogens once they enter the body. Thus, malnutrition predisposes to infections. Infections can alter nutritional status mediated by changes in dietary intake, absorption and nutrient requirements and losses of endogenous nutrients. Thus, the presence of infections can contribute to the malnourished state. The global burden of malnutrition and infectious disease is immense, especially amongst children. Childhood infections impair growth and development. There is a role for breast-feeding in protection against infections. Key nutrients required for an efficient immune response include vitamin $\mathrm{A}, \mathrm{Fe}, \mathrm{Zn}$ and $\mathrm{Cu}$. There is some evidence that provision of the first three of these nutrients does improve immune function in undernourished children and can reduce the morbidity and mortality of some infectious diseases including measles, diarrhoeal disease and upper and lower respiratory tract infections. Not all studies, however, show benefit of single nutrient supplementation and this might be because the subjects studied have multiple nutrient deficiencies. The situation regarding Fe supplementation is particularly complex. In addition to immunization programmes and improvement of nutrient status, there are important roles for maternal education, improved hygiene and sanitation and increased supply of quality water in the eradication of infectious diseases.
\end{abstract}

Malnutrition: Undernutrition: Infection: Immunity: Micronutrients

\section{Introductory comments}

Along with undernutrition, infection is a primary cause of morbidity and mortality in the developing world. Complex interactions exist between these two threatening problems. Despite a greater awareness of the implications of nutrient deficiencies in diminishing the host's

Abbreviations: AIDS, acquired immune deficiency syndrome; HIV, human immunodeficiency virus.
*Corresponding author: Dr Philip C. Calder, fax +44 (0) 23 80594383, email pcc@ soton.ac.uk 
defence towards infection, the increased understanding of the actions of different kinds of infectious agents, and the use of chemotherapy and immunization, malnutrition, nutrient deficiencies and infectious diseases persist. Increased survival through childhood has led to significant extension of life expectancy in developing countries. Nevertheless, globally one child in three does not survive to adulthood. The aim of this present article is to define the global burden of infectious disease, to identify the extent of malnutrition and micronutrient deficiencies and their impact on childhood growth, to describe some of the interactions between malnutrition and infectious disease, and to review some of the attempts to reduce the rates of morbidity and mortality from infectious disease by using nutritional interventions; in addition, some key aspects of the impact of nutritional deficiencies on immune function will be described. Many of these topics are vast, with a large number of studies in animal models as well as in community and hospital settings. As such, this article does not aim to review exhaustively the entire subject. However, the key issues will be highlighted. The reader is referred to Scrimshaw et al. $(1959,1968)$, Chandra (1983a, 1991), Tomkins \& Watson (1993) and Scrimshaw \& SanGiovanni (1997) for earlier, elegant, reviews of this topic.

\section{Malnutrition and infectious disease: the global burden}

Malnutrition and infection play a major role in the causation of preventable deaths and disabilities that occur within the developing world, especially among children. Improvements in health over the last 50 years or so, including immunization programmes, have brought about marked improvements in morbidity and mortality. Nevertheless, the global burden of malnutrition and infectious disease is enormous: it is estimated that at least 2 million children per year die from diseases for which vaccines already exist (World Health Organization, 1998). Low birth weight is an indicator of fetal undernutrition and WHO estimates that 25 million low birth weight babies are born each year, constituting $17 \%$ of all live births; $95 \%$ of these low birth weight infants are born in the developing world (World Health Organization, 1998). Born with low birth weights and then subjected to sub-optimal breast-feeding practices, these infants are at particular risk of malnutrition and disease. Low birth weight is associated with neonatal and postnatal mortality, particularly in Bangladesh and India (World Health Organization, $1997 a$, 1998). Because much $(50 \%)$ of the transfer of some nutrients from mother to fetus occurs in the last 6-8 weeks of gestation, prematurity and low birth weight are often associated with nutrient deficiencies (e.g. of $\mathrm{Zn}, \mathrm{Cu}, \mathrm{Fe}$ and vitamin A) (Farrell et al. 1985; Powers, 1993). Low birth weight increases susceptibility to diarrhoea and pneumonia, and increases risk of death from diarrhoea, pneumonia and measles (for review see Ashworth, 2000).

Inadequate dietary intake and disease are immediate causes of malnutrition and they reinforce one another synergistically (Scrimshaw et al. 1968; Fig. 1). Malnutrition makes the individual more susceptible to infection and decreases immune defences against invading pathogens. In turn, certain pathogens influence nutritional status, mediated by changes in dietary intake, absorption, and nutrient requirements and losses of endogenous nutrients (Fig. 2). Malnutrition takes several forms that often appear in combination, such as protein-energy malnutrition and deficiencies in micronutrients such as vitamin $\mathrm{A}, \mathrm{Fe}, \mathrm{Zn}$, and I. Growth of the individual is also impaired owing to the combination of poor nutrition, malabsorption and the host response to infection, which can involve anorexia and altered metabolism of nutrients. Infection also alters behaviour, which can affect feeding practices. 


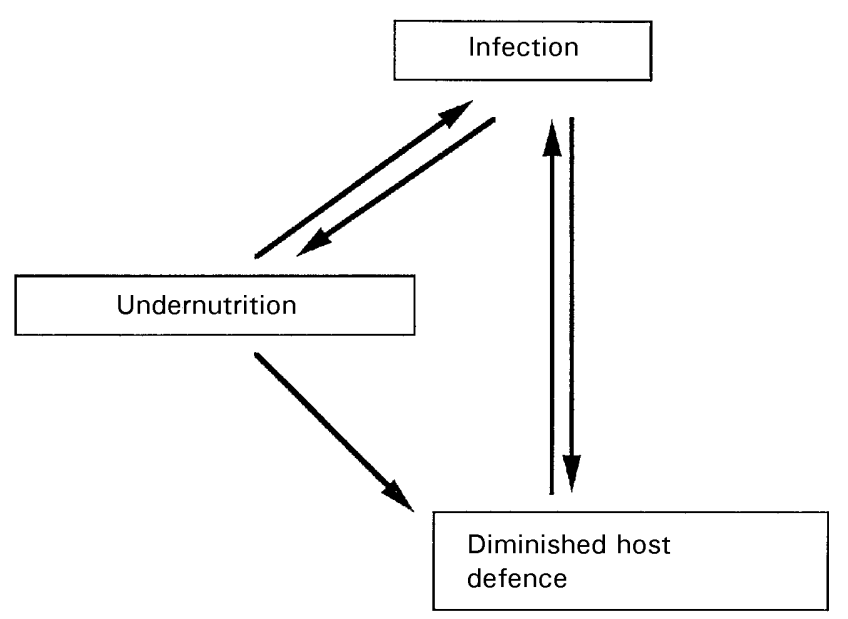

Fig. 1. Interrelationship between malnutrition and infection.

Malnutrition and infection can also occur in combination because of the environment which pertains. For example poverty, ignorance, poor hygiene, lack of water supplies, poor housing, poor health services, cultural practices, and discriminatory social structures often occur in combination and these create an environment of poor nutrition and exposure to infectious agents. Food and water can themselves be sources of infectious agents (Henry et al. 1990). A number of studies in different settings have now shown that improved sanitation and hygiene significantly reduce the incidence of diarrhoeal disease (Alam et al. 1989; Aziz et al.

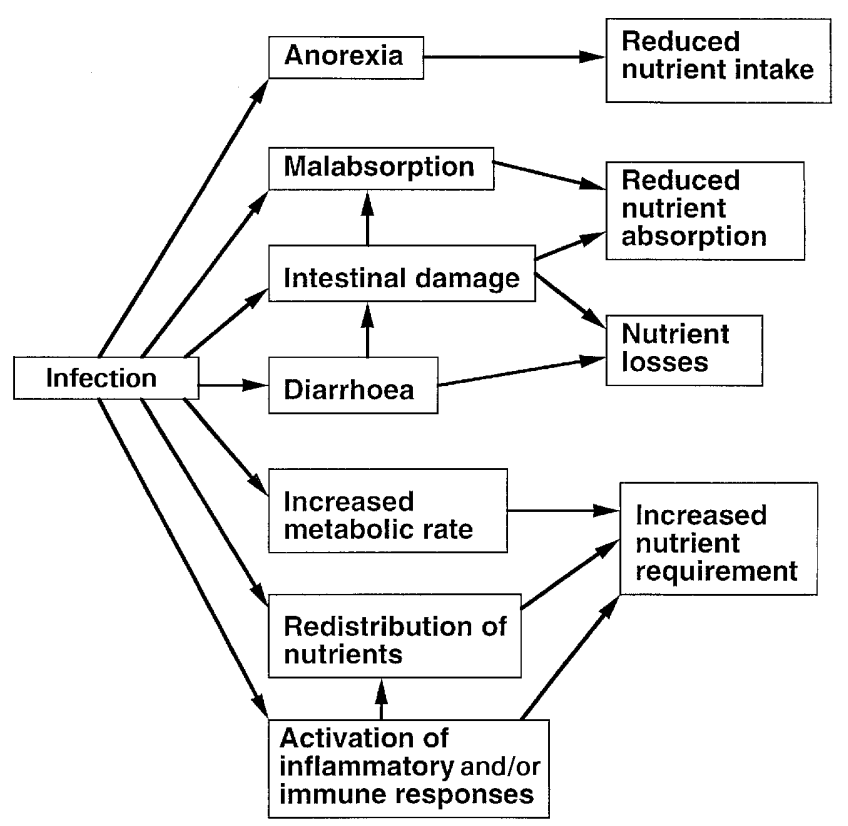

Fig. 2. Effects of infection on the host which can decrease nutrient status. 
1990; Henry \& Rahim, 1990; Ekanem et al. 1991; Haggerty et al. 1994; Alam, 1995; Gorter et al. 1998).

The disease burden of malnutrition is immense. Each year over 10 million children under 5 years of age die in developing countries, mainly from preventable causes; over 6 million of these deaths $(>50 \%)$ are directly or indirectly attributable to malnutrition (World Health Organization, 1998). In the developing world over 6 million children died in 1995 from one, or a combination of more than one of five, conditions: malaria, malnutrition, measles, acute respiratory infections, diarrhoea (Table 1). Over $30 \%$ of neonatal deaths are directly due to infection (World Health Organization, 1998). The great majority of maternal deaths (99\%) occur in the developing world (40\% of these are in South-East Asia); many of these deaths are due to infectious diseases related to malnutrition (World Health Organization, 1998).

Parasite infections are the most common infections globally. Among the protozoans, Plasmodium, Entamoeba and Giardia spp. infect 300-500 million, 500 million and 200 million individuals respectively, worldwide (Molyneux, 1997). Among the nematodes, Ascaris, schistomes, Trichuris and hookworm infect 1000 million, 200 million, 900 million and 500 million individuals respectively, worldwide (Molyneux, 1997). These infections are most common and most severe in children. The peak of infection is in childhood but the infections and their effects persist into adulthood.

WHO predicts that, by the end of 1999, 13 million women will have been infected with human immunodeficiency virus (HIV) and 4 million will have died of acquired immune deficiency syndrome (AIDS). Each day 1600 children become infected with HIV, mainly through mother-to-child transmission. By the end of 1999 as many as 10 million children under 10 years of age may have been orphaned as a result of maternal AIDS in sub-Saharan Africa alone and the projected deaths from AIDS may increase child mortality rates by as much as $50 \%$ in this region. Total numbers of individuals infected with HIV are estimated at 30 million in 1997, with 6 million new infections occurring per year. Of those infected with HIV (about 20 million) 60-65\% are in sub-Saharan Africa, with a further 6 million in South and South-East Asia and 1.3 million in South America.

One key change in the incidence of infectious disease in relatively recent times has been the re-emergence of tuberculosis (Bloom \& Murray, 1992). This disease, which has been a target of immunization programmes for many years, has re-emerged in both developed and developing countries. High-risk populations include those where malnutrition is common; in

Table 1. Major causes of death among children under 5 years of age in the developing world in $1995^{*}$

\begin{tabular}{lcc}
\hline Cause of death & $\begin{array}{c}\text { Deaths } \\
\text { (millions) }\end{array}$ & $\begin{array}{c}\text { Deaths associated with } \\
\text { malnutrition (\%) }\end{array}$ \\
\hline Lower respiratory tract infections & $2 \cdot 1$ & 44 \\
Diarrhoea & 2.0 & 70 \\
Prematurity & 1.0 & 40 \\
Measles & 1.1 & 65 \\
Birth asphyxia & 0.9 & 35 \\
Malaria & 0.7 & 40 \\
Congenital abnormalities & 0.5 & 30 \\
Pertussis & 0.4 & 50 \\
Neonatal tetanus & 0.4 & 20 \\
Birth trauma & 0.4 & 30 \\
Neonatal sepsis and meningitis & 0.4 & 30 \\
Malnutrition & 0.3 & 100 \\
Tuberculosis & 0.1 & 60 \\
All other causes & 0.2 & 40 \\
\end{tabular}

* Data from World Health Organization (1998). 
Table 2. Global burden of disease and injury attributable to selected risk factors*

\begin{tabular}{lcccr}
\hline Risk factor & $\begin{array}{c}\text { Total deaths } \\
\text { (millions) }\end{array}$ & $\begin{array}{c}\text { Total deaths } \\
(\%)\end{array}$ & $\begin{array}{c}\text { DALY } \\
\text { (millions) }\end{array}$ & $\begin{array}{c}\text { Total } \\
\text { DALY (\%) }\end{array}$ \\
\hline Malnutrition & 5.9 & 11.7 & 219.6 & 15.9 \\
Poor water, sanitation, hygiene & 2.7 & 5.3 & 93.4 & 6.8 \\
Unsafe sex & 1.1 & 2.2 & 48.7 & 3.5 \\
Tobacco & 3.0 & 6.0 & 36.2 & 2.6 \\
Alcohol & 0.8 & 1.5 & 47.7 & 3.5 \\
\hline
\end{tabular}

DALY, disability-adjusted life years.

* Data from Murray \& Lopez (1996).

developing countries the elderly are particularly at risk (Rajagopalan \& Yoshikawa, 1998) and this might be associated with their poorer nutrient status and the decline in immune function which accompanies ageing. Remarkably, tuberculosis is now the second most common cause of death in Indonesia (Gross \& Schultink, 1997). HIV infection causes a decline in host immune defences and this most likely explains the increased rates of infection of HIV patients with tuberculosis; tuberculosis is a major contributor to the body wasting that accompanies HIV infection in 'Slim disease' (Lucas et al. 1994). Globally, there are about 8.8 million new cases of tuberculosis each year and it is estimated to cause 3 million deaths per year (World Health Organization, 1995).

The Global Burden of Disease Study (Lopez, 1997) has calculated the future potential years of life lost or lived with a disability (disability-adjusted life years). In 1990 about 1.3 billion disability-adjusted life years were lost as a result of new cases of disease or injury; almost $90 \%$ of these occurred in developing countries. Of the major risk factors evaluated, malnutrition was by far the leading contributor to disability-adjusted life years worldwide, causing an estimated $16 \%$ of the global burden of disease in 1990 (18\% in developing countries), with contributions to disease burden being particularly evident in sub-Saharan Africa (33\%) and India (22\%) (Lopez, 1997). Malnutrition is the major cause of death, accounting for $11.7 \%$ of total deaths, followed by poor water and sanitation (Table 2) (Murray $\&$ Lopez, 1996). The ultimate cost of malnutrition cannot be accurately calculated. It includes visible costs (costs of drugs, hospitalization, transportation, food, treatment of non-nutritional diseases) which can be estimated but the undoubtedly larger invisible costs (including loss of family income and national productivity) cannot be readily quantified but must be immense.

\section{The incidence of childhood malnutrition}

It is estimated that 168 million children under 5 years of age (27\% of the world's children in this age group) are malnourished (as measured by weight-for-age); $76 \%$ of these children live in Asia, $21 \%$ in Africa and $3 \%$ in Latin America (World Health Organization, 1998). As many as 206 million children are stunted (i.e. height-for-age more than 2 SD below the mean value of the reference population; this equates to a height-for-age which is $<90 \%$ of the mean value of the reference population). In South Asia as many as $17 \%$ of children under 5 years of age are wasted (i.e. weight-for-height more than 2 SD below the mean value of the reference population; this equates to a weight-for-height which is $<80 \%$ of the mean value of the reference population) and $60 \%$ are stunted; figures for the developing world as a whole are $9 \%$ and $41 \%$ respectively. Worldwide, 160 million children are underweight (weight-for-age more than $2 \mathrm{SD}$ below the mean value of the reference population; this equates to a weight-for-age which is $<80 \%$ of the mean value of the reference population), with over half of these being in South 
Table 3. Regional variation in childhood malnutrition*

\begin{tabular}{lcccc}
\hline Region & $\begin{array}{c}\text { Low } \\
\text { weight-for-height } \dagger \\
\text { (wasted; \%) }\end{array}$ & $\begin{array}{c}\text { Low } \\
\text { height-for-age } \\
\text { (stunted; \%) }\end{array}$ & $\begin{array}{c}\text { Low } \\
\text { weight-for-age§ } \\
\text { (underweight; \%) }\end{array}$ & $\begin{array}{c}\text { Low } \\
\text { birthweight } \| \\
\text { (\%) }\end{array}$ \\
\hline South Asia & 17.1 & 59.5 & 58.3 & 33 \\
East and South-East Asia & 5.2 & 33.3 & 23.6 & 11 \\
Sub-Saharan Africa & 7.0 & 38.8 & 30.2 & 16 \\
Middle East and North Africa & 8.8 & 32.4 & 25.3 & 10 \\
Latin America and Caribbean & 2.6 & 22.7 & 12.0 & 11 \\
Developing countries & 9.1 & 40.7 & 33.9 & 19 \\
\hline
\end{tabular}

* Data are from United Nations (1994), United Nations International Children's Emergency Fund (1996), Food and Agriculture Organization (1996).

$\dagger$ Weight-for-height more than 2 SD below mean for reference population.

$\$$ Height-for-age more than 2 SD below mean for reference population.

II Small for gestational age: <10th centile of expected weight for gestational age for reference population.

Asia. In Bangladesh $10 \%$ of girls aged between 10 and 16 years and over $35 \%$ of those who were 15 years of age were stunted (Ahmed et al. 1998). In an earlier study from this group, as height-for-age and weight-for-age among Bangladeshi children aged 5-12 years increased, so did serum concentrations of haemoglobin, protein, vitamin A and Zn (Ahmed et al. 1993a). Table 3 provides information on the regional variation in childhood malnutrition.

\section{Malnutrition predisposes to infections}

Good nutrient status is required if the host is to combat infections effectively. Effective protection against invasion of the host by micro-organisms requires an intact skin surface and intact linings of the naso-oesophageal, gastrointestinal and genito-urinary tracts, since these provide a barrier to invasion. This barrier also includes the ability of cells to produce mucous secretions and to maintain other physiological protective mechanisms (e.g. pH). Importantly, the cells in these linings are continually turning over, so that nutrients required for cell growth and replication must be available in order for the protection against infection to be maintained. These barriers to invasion by infectious agents must be effective at all times. The immune response to infection involves a vast increase in cell differentiation and replication, in the production of immunoglobulins and acute-phase proteins and in the production of peptide- and lipid-mediators (cytokines and eicosanoids respectively); clearly, this will require an appropriate supply of nutrients to optimize the response. Finally, a component of the host response to infection is the production of damaging reactive $\mathrm{O}$ species; protection of the host from this damage requires an appropriate status of antioxidant protective mechanisms which include

Table 4. Prevalence of vitamin $A$ and iron deficiencies*

\begin{tabular}{|c|c|c|c|c|}
\hline \multirow[b]{2}{*}{ Region } & \multicolumn{2}{|c|}{$\begin{array}{c}\text { Children }<5 \text { years of age with } \\
\text { xerophthalmia in } 1991\end{array}$} & \multicolumn{2}{|c|}{$\begin{array}{l}\text { No. of women aged } 15 \text { to } \\
49 \text { years with low haemoglobin }\end{array}$} \\
\hline & $\begin{array}{l}\text { No. } \\
\text { (millions) }\end{array}$ & $\%$ & $\begin{array}{l}\text { No. } \\
\text { (millions) }\end{array}$ & $\%$ \\
\hline \multirow{6}{*}{$\begin{array}{l}\text { Africa } \\
\text { Latin America } \\
\text { South-East Asia including India } \\
\text { West Pacific including China } \\
\text { Asia including India and China } \\
\text { Total }\end{array}$} & 1.3 & 1.4 & 59.4 & 44 \\
\hline & 0.1 & 0.2 & 32.7 & 31 \\
\hline & 10 & 4.2 & & \\
\hline & 1.4 & $1 . \overline{3}$ & & \\
\hline & & & $335 \cdot 1$ & 45 \\
\hline & 13.8 & 2.8 & 427 & 44 \\
\hline
\end{tabular}

* Data from United Nations (1996). 
antioxidant enzymes (all of which include metal ions such as $\mathrm{Fe}, \mathrm{Zn}, \mathrm{Cu}, \mathrm{Mn}$ or $\mathrm{Se}$ as an active component), antioxidant vitamins (e.g. vitamin E, vitamin C) and small peptides (e.g. glutathione). Thus, in order to maintain protection against infective agents and to mount a successful response if infected, the host requires a supply of a range of nutrients. It is self-evident that the poorly nourished state is characterized by limited exogenous supply and endogenous reserve of nutrients. Thus, there is a vast body of evidence that many infections are increased in prevalence or severity by specific nutritional deficiencies (Scrimshaw et al. 1968). Table 4 indicates the extent of vitamin $\mathrm{A}$ and Fe deficiencies in the developing world.

\section{Vitamin A}

Vitamin A deficiency is associated with increased morbidity and mortality in children (Sommer et al. 1983, 1984; Milton et al. 1987) and may predispose to different types of respiratory infections (Solon et al. 1978; Tielsch et al. 1986; DeSole et al. 1987; Sommer et al. 1987; Bloem et al. 1990); these studies are population-, clinic- and hospital-based. Some populationbased studies fail to detect this association (Brilliant et al. 1985; Stanton et al. 1986; Gujral et al. 1993). However, prospective community-based studies confirm that there is an increased risk of respiratory disease in children with vitamin A deficiency (Sommer et al. 1984; Milton et al. 1987; Vijayaraghavan et al. 1990; Dibley et al. 1996). Vitamin A deficiency renders young children vulnerable to diarrhoea and to severe measles and high mortality (Markowitz et al. 1989; Butler et al. 1993). Although vitamin A deficiency increases the risk of infectious disease, the interaction is bidirectional such that infections can lead to vitamin A deficiency: diarrhoea, respiratory infections, measles, chickenpox and HIV infection are all associated with the development of vitamin A deficiency (Campos et al. 1987; Sommer et al. 1987; Rahman et al. 1996; Semba, 1997). Vitamin A status was not improved despite supplementation in Bangladeshi children with acute respiratory infections (Rahman et al. 1996); the authors interpreted this to mean that the presence of disease prevented a return to adequate status.

Vitamin A deficiency is common in HIV patients (Semba, 1997), and low plasma or serum vitamin A levels are associated with accelerated HIV progression (Baum et al. 1995), increased mortality (Semba et al. 1993), higher rates of transmission of HIV from mother to baby (Semba et al. 1994; Greenberg et al. 1997), child growth failure (Semba et al. 1997) and increased HIV load in breast milk and the birth canal (Nduati et al. 1995; John et al. 1997; Mostad et al. 1997). Breast milk is an important route of transmission of HIV from mother to child; the incidence of postnatal transmission of HIV through breast-feeding ranges from 4 to $32 \%$. Replacement feeding is the most effective measure to decrease transmission of HIV via breast milk; alternative measures include halting breast-feeding and using animal milk, or heat-treating breast milk.

\section{Iron}

Fe deficiency is the most common nutritional deficiency worldwide, affecting 1 billion people, particularly women of reproductive age and young children (United Nations, 1996). Anaemia among these groups is high in many regions (e.g. $77 \%$ of non-pregnant females aged 15-45 years in Bangladesh had haemoglobin levels below $100 \mathrm{~g} / 1$; Kolsteren et al. 1999). Fe deficiency is associated with gastrointestinal and respiratory infections (Berger et al. 1992). However, the influence of Fe status on infection is complicated by the fact that micro-organisms also require Fe (Payne \& Finkelstein, 1978). Thus, low Fe status should protect against 
the spread of infection and mechanisms have developed for withholding Fe from invading organisms: these include the higher affinity for Fe of lactoferrin than bacterial siderophores, and the sequestration of lactoferrin by macrophages once it has reached $40 \%$ saturation with $\mathrm{Fe}$ (Birgens et al. 1983; Baynes et al. 1986). Lactoferrin is found in human breast milk and probably plays a role in defence of the infant (Bullen et al. 1972). Thus, there is competition for Fe between the host immune system, host stores and invading pathogens.

The situation regarding Fe status and malaria is also complicated by the fact that it is the erythrocyte which is parasitized. The malaria parasite is totally dependent upon the erythrocytes of the host to complete its life cycle. This might explain the observation that malaria is more common in Fe-replete than Fe-deficient individuals (Oppenheimer et al. 1986).

\section{Zinc}

$\mathrm{Zn}$ deficiency is probably more widespread than is currently appreciated and may be an important contributor to childhood morbidity. Low plasma Zn levels predict the subsequent development of lower respiratory tract infections and diarrhoea among Indian infants (Bahl et al. 1988). Indeed, diarrhoea is considered a symptom of $\mathrm{Zn}$ deficiency. Low serum $\mathrm{Zn}$ is associated with more rapid HIV disease progression in homosexual men (Graham et al. 1991; Baum et al. 1995).

\section{Other nutrients}

In animal studies, as the level of protein in the diet decreases so the level of malaria parasitaemia and mortality decrease (Edirisinghe et al. 1981). However, this is not borne out in human subjects, where protein-energy malnutrition did not protect against malaria (Snow et al. 1991); however, this latter study did note that children experiencing clinical attacks with high parasitaemias tended to have higher weight-for-age at the start of the transmission season than children whose malaria attacks were associated with lower parasitaemia. Malaria parasites in erythrocytes are susceptible to oxidative stress. In animal models, decreasing vitamin $\mathrm{E}$ in the diet or feeding fish oil decreases parasitaemia and increases survival (Fevang et al. 1995; Levander et al. 1995; Taylor et al. 1997). Riboflavin deficiency also appears to protect against malaria, possibly owing to induction of oxidative stress (Das et al. 1990). Se deficiency was noted to be common in HIV infection and was linked to increased mortality (Baum et al. 1997). Many HIV patients have decreased circulating concentrations of vitamins $\mathrm{B}_{2}, \mathrm{~B}_{6}, \mathrm{~B}_{12}$, and $\mathrm{C}$ and niacin (see Semba \& Tang, 1999).

\section{Infections can cause malnutrition and can decrease growth in childhood}

\section{Infections can cause malnutrition}

Infections can alter nutritional status, mediated by changes in dietary intake, absorption, and nutrient requirements and losses of endogenous nutrients. Coupled with one or more existing nutrient deficiencies, the effect of infection can be particularly detrimental.

Infection is characterized by anorexia. Clearly, a reduction in food intake (anorexia) will result in reduced intake of all macro- and micronutrients. This could lead to nutrient deficiencies even if the host was not already deficient and it could make existing borderline 
deficiencies apparent. Guatemalan children with acute respiratory infections or diarrhoea consumed 8 and $18 \%$ less dietary energy per day respectively, than children without these infections (Martorell et al. 1980). In Bangladeshi children less than 5 years old, dietary energy intake was reduced by more than $40 \%$ during the acute stage of diarrhoea compared with that after recovery (Molla et al. 1983b). Energy intake among infants who were exclusively or partly breast-fed was less affected by illness, suggesting a protective effect of breast-feeding (Brown et al. 1990). Indeed, when energy intakes from breast milk and from other foods were examined separately, only the intakes from non-breast milk sources declined significantly (Brown et al. 1990). African children examined during the acute phase of measles consumed $75 \%$ less dietary energy than they did after recovery (Duggan et al. 1986). Withdrawal of food from individuals with fever, diarrhoea or other symptoms of infection is a common practice that will exacerbate the effects of anorexia. However, it is difficult to separate the effects of anorexia and food withdrawal but the combination could be devastating to the individual.

Infection is characterized by nutrient malabsorption and loss. The range of infections associated with nutrient malabsorption is wide and includes bacteria, viruses, protozoa and intestinal helminths. Apparent protein absorption by children in Panama with diarrhoea was generally reduced by $10-30 \%$ and sometimes by as much as $40 \%$ (see Scrimshaw \& SanGiovanni, 1997). In Bangladesh, absorption during diarrhoea caused by rotavirus averaged $43 \%$ for N, $42 \%$ for fat, $74 \%$ for carbohydrate and $55 \%$ for total energy (Molla et al. 1983a); absorption during diarrhoea caused by enteropathogenic Escherichia coli and Shigella spp. was slightly higher. Rates of absorption of macronutrients for healthy children would be expected to be $>90 \%$. Infection blocks Fe absorption (Cartwright et al. 1946). Vitamin A malabsorption also occurs during infections: children with acute diarrhoea, Ascaris infection or respiratory infections absorbed only 30-70\% of ingested vitamin A (Sivakumar \& Reddy, 1972, 1975). In contrast to these findings, Ahmed et al. (1993b) reported efficient ( $>95 \%$ ) absorption of a vitamin A dose among Ascaris-infected children in Bangladesh. Diarrhoea results in loss of $\mathrm{Zn}$ and $\mathrm{Cu}$ (Castillo-Duran et al. 1988). Measles infection increases nutrient losses in the faeces (Reddy et al. 1986; Markowitz et al. 1989; Butler et al. 1993). Diarrhoea and malabsorption of fat, carbohydrate, fat-soluble vitamins and vitamin $\mathrm{B}_{12}$ appear to be common to all stages of HIV infection (Miller et al. 1988, 1991; Harriman et al. 1989; Ehrenpreis et al. 1994; Castaldo et al. 1996; Koch et al. 1996).

Apart from malabsorption, nutrients may also be lost through the faeces as a result of damage to the intestinal wall. Measles and diarrhoea, especially due to Shigella, can lead to protein loss in the faeces. Nearly $65 \%$ of patients with enterotoxigenic E. coli and $40 \%$ of those with rotavirus diarrhoea had excessive losses of protein in their faeces (see Scrimshaw \& SanGiovanni, 1997). In patients with shigellosis, $100-500 \mathrm{ml}$ serum was lost in the faeces each day (see Scrimshaw \& SanGiovanni, 1997). Intestinal helminths, especially hookworm infections, cause gastrointestinal loss of blood (and energy) and these are a major cause of $\mathrm{Fe}-$ deficiency anaemia in some regions. Each adult hookworm can cause a loss of up to $250 \mathrm{mg}$ blood and $4.2 \mathrm{~kJ}$ energy per $\mathrm{d}$ (Briscoe, 1979). Less than one-half of Fe lost this way is reabsorbed. Total blood loss during helminth infection could be greater than $5 \mathrm{ml} / \mathrm{d}$ (Pawlowski et al. 1991). Severe infection with whipworm (Trichuris spp.) alters the large intestine mucosa leading to loss of erythrocytes and plasma; this infection is associated with decreased haemoglobin levels, reduced erythrocyte volume and reduced erythrocyte haemoglobin (Ramdath et al. 1995). Haemoglobin concentration is negatively associated with the number of Trichuris eggs appearing in the faeces, a measure of infestation (Ramdath et al. 1995). Infection with Schistosoma haematobium, which directly damages the wall of the bladder, can lead to blood loss in the urine and this can contribute to Fe deficiency. Protein and nutrients are also lost in 
the urine as a result of infection; of importance is the loss of retinol-binding protein (the serum transport protein for vitamin A) which is lost increasingly in the urine as the severity of infections increases (Stephenson et al. 1994).

Infection is characterized by increased resting energy expenditure. Infection increases BMR: there is a $13 \%$ increase for each $1^{\circ}$ increase in body temperature. During a period of high fever, metabolism may increase by nearly one-third (DuBois, 1936), so increasing the requirement for energy-yielding nutrients and the cofactors which participate in their metabolism. This places a significant drain on body pools of nutrients particularly when coupled with anorexia, diarrhoea and other nutrient losses (e.g. in urine and sweat). The increase in resting energy expenditure has been well documented in HIV infection (Melchior et al. 1993). Asymptomatic HIV-infected individuals had a $16 \%$ greater resting energy expenditure than uninfected individuals, while HIV-infected subjects who also had other opportunistic infections had a $57 \%$ greater resting energy expenditure than controls. The increased energy expenditure often occurs in combination with anorexia and malabsorption, resulting in body wasting (for review see Macallan, 1998). Macallan et al. (1995) showed that the weight loss among British adults with HIV infection was largely a consequence of reduced energy intake, rather than increased energy expenditure.

Infection is characterized by altered metabolism and redistribution of nutrients. The acutephase response is the name given to the metabolic response to infections (and often to immunization) and it includes the onset of fever and anorexia, the production of specific 'acutephase reactants' and the activation and proliferation of immune cells. Such a catabolic response occurs with all infections even when they are subclinical (Beisel, 1972, 1975; Keusch \& Farthing, 1986). This serves to cause redistribution of nutrients away from skeletal muscle and adipose tissue and towards the host immune response. This redistribution is mediated by production of pro-inflammatory cytokines by leucocytes and associated endocrine changes. These lead to mobilization of amino acids, primarily from skeletal muscle, which are used as gluconeogenic substrates in the liver with the $\mathrm{N}$ released being lost in the urine. Some of the amino acids are used by the liver for the synthesis of the so-called acute-phase proteins and by leucocytes and other cells for synthesis of immunoglobulins and cytokines. The average loss of protein over a range of infections has been estimated to be $0.6 \mathrm{~g} / \mathrm{kg}$ per d (Powanda, 1977). Diseases associated with diarrhoea or dysentery produce a higher protein loss than this $(0.9 \mathrm{~g} / \mathrm{kg}$ per $\mathrm{d})$, with severe infections such as typhoid fever inducing even greater loss $(1.2 \mathrm{~g} / \mathrm{kg}$ per d) (Powanda, 1977). Tuberculosis infection leads to loss of both lean and fat tissue by 15-20\% (Onwubalili, 1988). Kennedy et al. (1996) showed that anti-tuberculosis drugs caused weight gain in all subjects studied. The metabolic response to infection also results in increased oxidant stress (Grimble, 1999), which can potentially deplete reserves of cellular and plasma antioxidant vitamins (vitamin E, vitamin C, $\beta$-carotene; Grimble, 1999).

One metabolic consequence of infection is a decrease in serum $\mathrm{Fe}, \mathrm{Zn}$ and vitamin $\mathrm{A}$ concentrations. There are contrasting views as to the role of this: one is that the nutrients are preferentially moved to tissue sites to promote host defence and the other is that they are cleared from the circulation in order to deprive pathogens of nutrients that they need. These alternatives are important in understanding the meaning and role of changes in plasma concentrations and in designing appropriate nutritional interventions. For example, it might be wrong to interpret low blood levels as defining a deficiency state. Correspondingly, it may be unwise or even impossible to restore 'normal' circulating levels of micronutrients during episodes of infection. Furthermore, an infection which causes diarrhoea and so results in vitamin $\mathrm{A}, \mathrm{Fe}$ and $\mathrm{Zn}$ loss in the faeces, involves an interaction between redistribution of these nutrients within the body and loss of these nutrients from the body. 
Childhood infections decrease growth

Mata et al. (1977) (see also Mata, 1992) very elegantly showed the relationship between nutrition, infection and growth in children. Fig. 3 shows the growth curve of an individual child: before weaning (about 6 months of age) the child is growing at the expected rate, despite the occurrence of infections. After weaning there is a high incidence of infections (particularly those due to diarrhoeal pathogens) and these episodes of infection are associated with weight loss. The high frequency of infections also limits the opportunity for catch-up growth between episodes of infection.

Diminished weight gain, an indicator of infection and/or malnutrition, has been associated with increased rates of diarrhoeal and respiratory diseases in a number of studies (e.g. Ballard \& Neumann, 1995). As weight-for-age decreases so the duration and severity of diarrhoea increases (Martorell et al. 1975; Condon-Paolini et al. 1977; Rowland et al. 1977; Black et al. 1984; Zumrawi et al. 1987; Briend et al. 1989; Lutter et al. 1989; Moy et al. 1994; Morris et al. 1996).

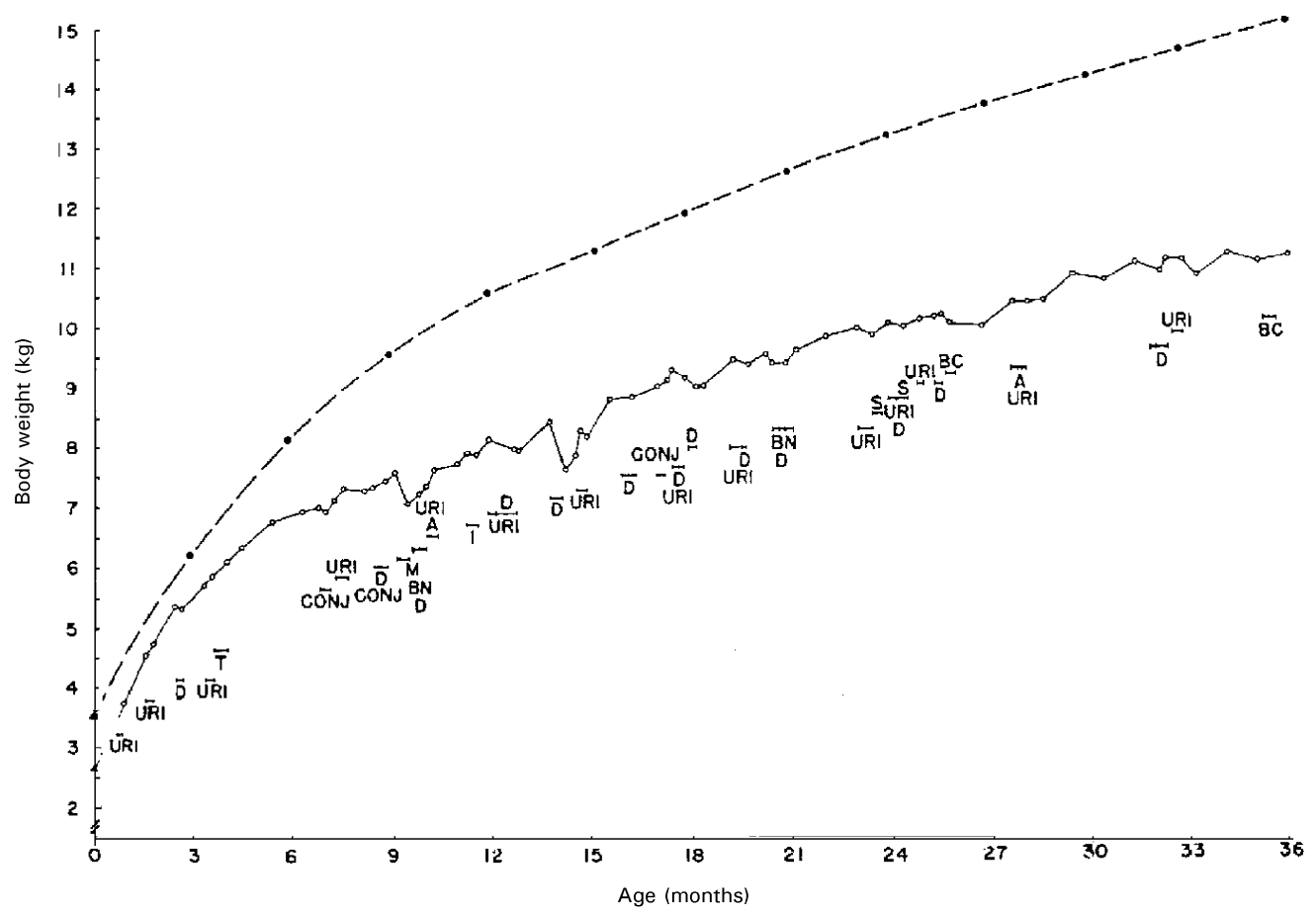

Fig. 3. Association between repeated episodes of infection and weight gain of a Guatemalan child during the first 3 years of life. (o-o) The weight of the child; $(\bullet--\cdot \bullet)$, the median of the weightfor-age standard curve; A, abcess; BC, bronchitis; BN, bronchopneumonia; CONJ, conjunctivitis; $\mathrm{D}$, diarrhoea; I, impetigo; M, measles; S, stomatitis; T, oral thrush; URI, upper respiratory tract infection. The length of the horizontal lines indicates the duration of individual episodes of infectious disease. Adequate growth was seen during the period of exclusive breast-feeding and subsequent weight loss was associated with periods of infection. Reproduced from Mata et al. (1977) with permission from the American Society for Clinical Nutrition. 
The association between infections and linear growth is more difficult to document than the association with weight. This is because height does not decrease (weight does) and because longer time intervals are required to document linear growth than to document weight changes. However, such associations have been observed. A longitudinal study of Guatemalan children ( $<7$ years of age) found that those with a high prevalence of diarrhoea had slower linear growth than those with a low prevalence (Martorell et al. 1975). In the Gambia, infants in the first year of life showed reduced increase in length (by about $1 \mathrm{~mm} /$ week) during diarrhoea compared with their own growth rate during diarrhoea-free periods (Rowland et al. 1977). A similar study in rural Bangladesh showed that a child without diarrhoea would gain on average $42 \mathrm{~mm} /$ year more than a child with the average prevalence of diarrhoea (13\% of days) (Black et al. 1984). However, not all diarrhoeal pathogens appear to have the same impact on growth; Shigella infection was associated with impaired linear growth whereas infection with E. coli or rotavirus was not (Black et al. 1984). In Brazil, hospitalization of children for either diarrhoea or pneumonia during a 2-year period was associated with diminished linear growth over that period of time, with the effect of diarrhoea being greater than that of pneumonia (Victora $e t$ al. 1990). Infection with Ascaris and other gut helminths is associated with impaired linear growth (Stephenson, 1987; Hlaing, 1993). Early infection with HIV is also associated with impaired linear growth: a 6-year longitudinal study of the growth of infants born to HIV-infected mothers showed that those infants who were infected perinatally with HIV had impaired linear growth by 15 months of age compared with infants who were not HIV infected and eventually had a height deficit of about $80 \mathrm{~mm}$ (Saavedra et al. 1995). Interestingly, this impairment of linear growth was apparent well before an impairment in weight gain (which was not decreased until 36 months of age; Saavedra et al. 1995), suggesting that HIV infection might have a specific effect on long-bone growth, perhaps by infection of osteoclasts by HIV.

The urinary lactulose : mannitol ratio, an indicator of gut permeability, increased as infant growth (height or weight) decreased, suggesting that impaired growth is associated with gut dysfunction (Lunn et al. 1991) which will, in turn, decrease nutrient availability.

\section{Nutrition and immune function}

There is now overwhelming evidence from both animal studies and studies with human subjects that particular nutrients are required for an optimal immune response and that deficiencies in one or more of these nutrients diminish immune function and provide a window of opportunity for infectious agents. It is logical that multiple nutrient deficiencies might have a more significant impact on immune function, and so on resistance to infection, than would a single nutrient deficiency.

A large number of studies in animals have demonstrated the adverse effects of protein deficiency on immunity and these effects have been confirmed in various human settings (e.g. Chandra, 1975, 1979, 1983b; Chandra et al. 1982, 1984). It is not surprising that protein deficiency diminishes immune responses and increases susceptibility to infection because immune defences are dependent upon cell replication and the production of proteins with biological activities (e.g. immunoglobulins, cytokines, acute-phase proteins). Practically all forms of immunity may be affected by protein-energy malnutrition, but non-specific defences and cell-mediated immunity are more severely affected than humoral (antibody) responses (Table 5) (for review see Kuvibidila et al. 1993); indeed, circulating concentrations of immunoglobulins are often unaffected by malnutrition (see Kuvibidila et al. 1993). That impaired immunity has a functional consequence was shown by a study in malnourished 
Table 5. The effect of protein-energy malnutrition on immune function

\begin{tabular}{lc}
\hline Function and/or test & Response \\
\hline Weight of thymus, spleen, tonsils & $\Downarrow$ \\
Leucocyte counts & $\leftrightarrow$ \\
T lymphocytes in blood & $\Downarrow$ \\
CD4 cells in blood & $\Downarrow$ \\
CD8 cells in blood & $\Downarrow$ \\
CD4: CD8 in blood & $\Downarrow$ \\
Blood lymphocyte proliferation & $\Downarrow$ \\
TNF, IL-1 and IL-6 production & $\Downarrow$ \\
IL-2 and IFN- $\gamma$ production & $\Downarrow$ \\
B lymphocytes in blood & $\Leftrightarrow$ \\
Antibody response & $\Downarrow$ \\
Immunoglobulin A in tears, saliva & $\Downarrow$ \\
Thymulin levels in blood & $\Downarrow$ \\
Activity of leucocytes to kill bacteria & $\Downarrow$ \\
Delayed-type hypersensitivity response & $\Downarrow$ \\
\hline
\end{tabular}

$\Downarrow$, Decreased; $\Leftrightarrow$, not affected; TNF, tumour necrosis factor; IL, interleukin; IFN, interferon.

Bangladeshi children: those who showed the fewest skin reactions to common bacterial antigens (i.e. the weakest cell-mediated immune response) had a greater incidence of diarrhoeal disease (Koster et al. 1987; Baqui et al. 1993). In addition to reduced protein availability, deficiencies in specific amino acids may affect immune function.

Experimental animals made deficient in vitamin A have impaired immunity (Table 6) and increased susceptibility to infection (for review see Semba, 1998). Vitamin A-deficient mice were more susceptible to rotavirus infection (Ahmed et al. 1990), and had lower serum specific antibody levels after challenge with rotavirus and a decreased delayed-type hypersensitivity response (Ahmed et al. 1991). Vitamin A is also essential for maintaining epidermal and mucosal integrity, and vitamin A-deficient mice had histopathological changes in the gut mucosa consistent with a breakdown in gut barrier integrity and had a decreased number of goblet cells in the small intestine villi, suggestive of impaired mucus secretion (Ahmed et al. 1990).

Fe deficiency has multiple effects on immune function (Table 6) (for review see Sherman \& Spear, 1993). There was a positive correlation between Fe status in malnourished Indian children and lymphocyte proliferation, phagocytic respiratory burst and bacterial killing by phagocytes (Chandra, 2000). Natural killer cell activity and interleukin 2 production are enhanced when Fe-deficient children are given Fe supplements (Chandra, 2000).

$\mathrm{Zn}$ deficiency in animals is associated with a wide range of immune impairments including thymic atrophy, depressed cell-mediated immunity and increased susceptibility to infections (Table 6) (for review see Fraker et al. 1993). In acrodermatitis enteropathica, which is char-

Table 6. The effect of nutrient deficiencies on immune function

\begin{tabular}{|c|c|c|c|c|c|}
\hline \multirow[b]{2}{*}{ Nutrient deficiency } & \multicolumn{5}{|c|}{ Effect on } \\
\hline & $\begin{array}{l}\text { Thymus } \\
\text { weight }\end{array}$ & $\begin{array}{c}\text { No. of } \mathrm{T} \\
\text { lymphocytes }\end{array}$ & $\begin{array}{l}\text { Lymphocyte } \\
\text { proliferation }\end{array}$ & $\begin{array}{c}\text { IL- } 2 \\
\text { production }\end{array}$ & DTH \\
\hline $\begin{array}{l}\text { Vitamin A } \\
\text { Iron } \\
\text { Zinc } \\
\text { Selenium } \\
\text { Copper }\end{array}$ & $\begin{array}{l}\Downarrow \\
\Downarrow \\
\Downarrow \\
\Downarrow \\
\Downarrow\end{array}$ & $\begin{array}{l}\Downarrow \\
\Downarrow \\
\Downarrow \\
\Downarrow \\
\Downarrow\end{array}$ & $\begin{array}{l}\Downarrow \\
\Downarrow \\
\Downarrow \\
\Downarrow \\
\Downarrow\end{array}$ & $\begin{array}{l}\Downarrow \\
\Downarrow \\
\Downarrow \\
\Downarrow \\
\Downarrow \\
\Downarrow\end{array}$ & $\begin{array}{l}\Downarrow \\
\Downarrow \\
\Downarrow \\
\Downarrow \\
\Downarrow\end{array}$ \\
\hline
\end{tabular}

$\Downarrow$, Decreased; IL, interleukin; DTH, delayed-type hypersensitivity. 
acterized by reduced intestinal $\mathrm{Zn}$ absorption, thymic atrophy, impaired lymphocyte development and reduced lymphocyte responsiveness are observed. $\mathrm{Zn}$ administration to such patients and others with $\mathrm{Zn}$ deficiency improves immune-cell function and the delayed-type hypersensitivity response (Shankar \& Prasad, 1998). Malnourished Zn-deficient children given $\mathrm{Zn}(2 \mathrm{mg} / \mathrm{kg}$ body weight per $\mathrm{d}$ for $10 \mathrm{~d})$ had increased thymus size as judged by radiography (Golden et al. 1977). Topical application of $\mathrm{Zn}$ to malnourished children improved the delayedtype hypersensitivity response in the area of skin on which the application was made (Golden et al. 1978). Zn administration to pre-term low body weight infants $(1 \mathrm{mg} / \mathrm{kg}$ per $\mathrm{d}$ for $30 \mathrm{~d})$ increased the number of circulating $\mathrm{T}$ lymphocytes and lymphocyte proliferation (Chandra, 1991). Providing $5 \mathrm{mg} \mathrm{Zn/d}$ to low birth weight, small-for-gestational-age infants for 6 months increased measures of cell-mediated immune function and decreased the incidence of gastrointestinal and upper respiratory tract infections (Lira et al. 1998); a Zn dose of $1 \mathrm{mg} / \mathrm{d}$ was without effect. Zn-sufficient mice had a lower helminth burden than those which were $\mathrm{Zn}$ or protein deficient (Shi et al. 1998). Excessive $\mathrm{Zn}$ intakes impair immune responses: for example, $150 \mathrm{mg} \mathrm{Zn}$ given twice daily for 6 weeks to young adult human subjects decreased lymphocyte and phagocyte function (Chandra, 1984).

$\mathrm{Cu}$ deficiency impairs immune function in experimental animals, and $\mathrm{Cu}$ deficiency in experimental animals is associated with increased morbidity and mortality to a Salmonella typhimurium challenge (for reviews see Prohaska \& Failla, 1993; Failla \& Hopkins, 1998). Children with Menke's syndrome, a rare congenital disease resulting in $\mathrm{Cu}$ deficiency, have increased bacterial infections, diarrhoea and pneumonia (Vyas and Chandra, 1983).

Deficiencies in many other micronutrients including $\mathrm{Mg}$, Se, vitamin $\mathrm{C}, \beta$-carotene, pyridoxine, folic acid, vitamin $\mathrm{B}_{12}$ and vitamin $\mathrm{E}$ reduce immune function in experimental animals and in human populations (for reviews see Bendich, 1993; Siegel, 1993; Stabel \& Spears, 1993; Scrimshaw \& SanGiovanni, 1997), and may play a role in increasing susceptibility to infections.

\section{Improved nutrition, including breast-feeding of infants, can reduce infection rates and the impact of infection on growth}

The thymus was twice as large, as determined by ultrasound, in 4-month-old Danish infants who had been exclusively breast-fed since birth than in those who had been exclusively formula-fed; thymus size in partially breast-fed infants was intermediate (Hasselbalch et al. 1996). This study suggests that breast milk contains immunostimulating factors which aid early development of the immune system and which will be most likely to help the infant combat infection. This idea is supported by the data of Mata et al. (1977) (Fig. 3) which suggest that breast-feeding might reduce the incidence of infections. If this is so, then it is probably due to a combination of factors including better nutrient supply (both quantity and quality) than that received post-weaning, and decreased exposure to infectious agents. Other studies support the notion that breast-feeding has a key role in the prevention of infectious disease. Infants in Peru were divided into five feeding categories (exclusively breast-fed, water + breast-feeding, milk + breast-feeding, solids + breast-feeding, no breast-feeding); the risk of diarrhoea, respiratory infections and mortality was lowest in the exclusively breast-fed group and highest in the group that were not breast-fed (Brown et al. 1989). In the absence of diarrhoea, linear growth of those infants fed exclusively by breast was 3 -fold higher than those who were not breast-fed. The prevalence of diarrhoea did not affect growth of exclusively breast-fed Peruvian infants whereas it reduced the growth of those who were not breast-fed (Brown et al. 1991). A study in Scotland found that babies who were breast-fed for 13 or more weeks had significantly less gastrointestinal illness than those who were bottle-fed from birth (Howie et al. 1990); the 
protective effect of breast-feeding was maintained beyond the breast-feeding period and resulted in a decreased rate of hospital admissions. Breast-feeding for less than 13 weeks was not protective (Howie et al. 1990). Golding et al. $(1997 a, b, c)$ have reviewed the impact of breast-feeding and conclude that during the first $4-6$ months of life it protects against gastroenteritis and diarrhoea in both the developed and developing world and that it may be protective against lower, but probably not against upper, respiratory tract infections.

One other important aspect of the impact of the type of infant feeding to consider is the marked differences in the composition of human compared with cows' milk. Human milk is rich in immunoglobulins, in the antimicrobial proteins lactoferrin (which binds $\mathrm{Fe}$, so preventing its uptake by bacteria) and lysozyme (which has direct antibacterial action), in vitamins $\mathrm{A}, \mathrm{D}$ and $\mathrm{E}$, in polyunsaturated fatty acids and in free amino acids; in contrast, cows' milk either lacks or contains only traces of these factors. Jackson \& Golden (1978) speculate that the role of cows' milk is to aid development of the rumen in the calf; thus the composition of cows' milk should be one which will promote bacterial growth in the gastrointestinal tract. Clearly, this is undesirable in the human neonate and could have disastrous consequences, particularly when combined with exposure to micro-organisms.

Prisoners of war who received Red Cross food parcels had a lower incidence of tuberculosis $(1.2 \%)$ compared with those who did not receive food parcels (15\%) (Leyton, 1946). A recent trial in Vietnam showed that home-production of foods and nutrition education was associated with a decreased incidence of acute respiratory infections among children aged 1-6 years (11.2\% v 49.1\% in the control group; English et al. 1997). During a measles outbreak in India, infected children who had received and continued to receive a food supplement (1.30 MJ ( $310 \mathrm{kcal})$ plus $3 \mathrm{~g}$ protein per d) gained weight at the same rate as non-infected children whereas those who were infected but had not received the food supplement lost weight (Gopalan et al. 1973).

\section{Can supplementation with specific nutrients influence the incidence and severity of infectious disease?}

Deficiencies of vitamin $\mathrm{A}, \mathrm{Zn}, \mathrm{Fe}$ and other micronutrients are widespread in the developing world (see earlier). Such deficiencies impair the immune response (see earlier), which probably makes the host less resistant to infection. Thus, provision of these nutrients should improve immune function and so diminish the severity and duration of infectious diseases. Ultimately this effect could decrease mortality from these diseases.

\section{Vitamin A}

There have been a number of studies of vitamin A administration and morbidity and mortality in children; most, though not all, of these studies show large drops in mortality (Muhilal et al. 1975; Sommer et al. 1986; Rahmathullah et al. 1990). Indonesian infants given vitamin A (15 mg retinol equivalents) orally at birth had half the mortality rate of a control group during the first year of life (Humphrey et al. 1996). Several studies demonstrate a decline (by 18$76 \%$ ) in measles-related deaths in vitamin A-deficient children supplemented with vitamin A (Barclay et al. 1986; Hussey \& Klein, 1990; Rahmathullah et al. 1990; Vijayaraghavan et al. 1990; West et al. 1991; Daulaire et al. 1992; Herrera et al. 1992; Ghana VAST Study Team, 1993). Hussey \& Klein (1990) showed that South African children given vitamin A had fewer complications arising from measles, with a resulting shorter hospital stay and less-frequent 
intensive care than the placebo group. Coutsoudis et al. (1991) showed that vitamin A administration to South African children with measles resulted in increased weight gain and a reduction in episodes of diarrhoea, upper respiratory tract infections and pneumonia. The severity of measles was also diminished after vitamin A supplementation in children in Kenya (Ogaro et al. 1993) and India (Sinha \& Bang, 1976). A meta-analysis of nine vitamin A supplementation studies showed a $30 \%$ decrease in measles-related mortality in children aged more than 6 months after vitamin A supplementation (Fawzi et al. 1993). Glasziou \& Mackerras (1993) also conducted a meta- analysis of vitamin A supplementation trials and concluded that vitamin A reduces measles deaths by $55 \%$; they excluded one large study (Herrera et al. 1992) which was included by Fawzi et al. (1993) and which showed no significant impact of vitamin A on child mortality from measles. WHO recommends that, in areas where the measles fatality rate is greater than $1 \%$, children with measles should be supplemented with vitamin A (World Health Organization, 1997b).

A number of studies have shown that vitamin A supplementation decreases the severity but not the incidence of diarrhoea in children (Bloem et al. 1990; Ghana VAST Study Team, 1993; Lie et al. 1993; Barreto et al. 1994; Bhandari et al. 1994; Biswas et al. 1994; Sempertegui et al. 1999). However, some vitamin A supplementation studies do not report a reduction in either incidence or severity of diarrhoea (Rahmathullah et al. 1991; Ramakrishnan et al. 1995). It is possible that those studies which show no effect of vitamin A supplementation included children with deficiencies in other nutrients. In addition, it appears that age might influence the effectiveness of vitamin A: in a study of Indonesian children Dibley et al. (1996) found that, while overall there was no effect of vitamin A supplementation on the incidence of diarrhoea, vitamin A tended to increase incidence in children $<30$ months of age and to decrease incidence in older children.

A number of trials of vitamin A supplementation in respiratory tract infections have been performed. A meta-analysis of twelve large field trials (The Vitamin A and Pneumonia Working Group, 1995) failed to detect significant effects on incidence or mortality. Five of these trials had information on pneumonia incidence and prevalence and overall there was no effect; indeed, there was a trend towards a possible harmful effect of vitamin A supplementation in 6-11-month-old infants, but a beneficial effect in those 4-5 years old. One study showed a significant reduction in pneumonia incidence (Daulaire et al. 1992). Some smaller trials have shown a beneficial impact of vitamin A on respiratory morbidity (Bloem et al. 1990; Lie et al. 1993). Pneumonia mortality has been assessed in five trials of vitamin A supplementation: the impact varied but for most studies the effect of vitamin A was the same as the placebo (Rahmathullah et al. 1990; West et al. 1991; Daulaire et al. 1992; Ghana VAST Study Team, 1993). A number of randomized, placebo-controlled trials have failed to show any beneficial effects of vitamin A supplementation in infants and children with acute onset of lower respiratory tract infections (Kjolhede et al. 1995; Bresee et al. 1996; Dowell et al. 1996; Nacul et al. 1997); indeed, some of these studies show adverse effects of vitamin A (Bresee et al. 1996). This may relate to the nutritional status of the infants. A recent study (Sempertegui $e t$ al. 1999) reported that vitamin A (3 mg retinol equivalents per week for 40 weeks) decreased the incidence of lower respiratory tract infections in underweight children compared with placebo treatment, but increased the incidence in normal-weight children. Supplementation of Australian children with a history of respiratory infections caused a reduction in rate of lower respiratory disease of $25 \%$ (Pinnock et al. 1986). Shenai et al. (1987) reported reduced incidence of bronchopulmonary dysplasia in vitamin A-deficient low birth weight infants given vitamin A.

Vitamin A supplementation resulted in a significant reduction in mortality and morbidity among HIV-infected children (Coutsoudis et al. 1995). In contrast, a single oral dose of 
vitamin A did not alter HIV load in intravenous drug users in Baltimore (Semba et al. 1998). Semba et al. (1994) reported that mother-to-child transmission rates of HIV increased as the concentration of vitamin A in maternal plasma decreased, and suggested that maternal vitamin A deficiency contributed to mother-to-child transmission. Despite this, maternal vitamin A supplementation throughout the third trimester of pregnancy and at delivery did not alter the rate of mother-to-child HIV transmission up to 3 months of age of the infants (Coutsoudis $e t$ al. 1999). The effect of supplementation with vitamin A or multivitamins alone or in combination has been investigated in a placebo-controlled trial in pregnant women with HIV infection. Multivitamins decreased fetal death (miscarriage and stillbirth), lowered the incidence of low birth weight (by $40 \%$ ), lowered the rate of severe pre-term births ( $<34$ weeks) and decreased the number of small-for-gestational-age infants; vitamin A was without effect (Fawzi et al. 1998). Likewise, multivitamins, but not vitamin A, increased CD4 and CD8 counts, the number of T lymphocytes and haemoglobin levels (Fawzi et al. 1998). In another study, a combination of drug and micronutrient (vitamins A, C, E and Se and Zn) therapy did not decrease diarrhoea or mortality over 1 month compared with drug plus placebo in AIDS patients in Zambia (Kelly et al. 1999).

\section{Iron}

The situation relating to Fe supplementation is complex: although an efficient immune response requires $\mathrm{Fe}$, micro-organisms also require $\mathrm{Fe}$ for multiplication and it has been argued that the decline in circulating Fe concentrations which accompanies infection is an attempt by the host to 'starve' the infectious agent of Fe. Thus, providing Fe to an infected individual could make the infection worse. The complication of the competition between host and invader for available $\mathrm{Fe}$ is illustrated by the observation that Fe-deficient rats display the same level of protection against Salmonella as do Fe-replete rats (Baggs and Miller, 1973). Indeed if Fedeficient individuals who have compromised resistance to infection are given large doses of $\mathrm{Fe}$ parenterally or orally, an exacerbation of infection and death can occur (McFarlane et al. 1970; Brock, 1993). Likewise, parenteral Fe administration to low birth weight babies increased the incidence of septicaemia (Barry \& Reeve, 1974). Chilean children who received Fe-fortified milk (12 mg Fe/l) had a $20 \%$ higher incidence of diarrhoea than those who received a control milk containing $1 \mathrm{mg} \mathrm{Fe} / 1$ (Brunser et al. 1993). Likewise, Bangladeshi children aged 2-48 months who received supplemental $\mathrm{Fe}(15 \mathrm{mg} / \mathrm{d}$ for 15 months) in addition to vitamins A, D and $\mathrm{C}$, had $26 \%$ more days with diarrhoea than children who received the vitamins alone (Mitra et al. 1997); the detrimental effect of Fe was even greater among children $<12$ months of age. There were no differences in acute respiratory infections between the two groups (Mitra et al. 1997). In contrast to these studies, Heresi et al. (1995) reported no difference in incidence or severity of diarrhoeal or respiratory infections between infants receiving Fe-fortified and non-fortified milk.

In contrast to these observations, supplementation of poorly nourished individuals with low amounts of $\mathrm{Fe}$ (up to $100 \mathrm{mg} / \mathrm{d}$ for adults and proportionally less for children) can in some cases result in decreased frequency and severity of infectious disease. For example, compared with a placebo, Fe supplementation for 12 weeks decreased infectious morbidity in Indonesian school children (Chwang et al. 1988).

As indicated earlier, the situation regarding Fe status and malaria is particularly complicated because the malaria parasite infects erythrocytes. Since reduced Fe availability decreases the number of erythrocytes, low $\mathrm{Fe}$ status should protect against malaria (indeed, the incidence 
of malaria in Fe-deficient individuals is less than in Fe-replete individuals; Oppenheimer et al. 1986) and giving Fe to malaria-infected individuals should make the disease worse. Indeed, it could be argued that lowering Fe status might improve malaria outcome: this is borne out by the observation that Fe chelation therapy enhanced the clearance of parasites and speeded up the effect of anti-malarials (Thuma et al. 1998). Earlier studies showed that levels of malaria infection and the severity of the disease were increased by Fe supplementation (Murray et al. $1978 a, b)$. In contrast Fe supplementation did not affect the rate of malarial infection in Tanzanian infants (Menendez et al. 1997). However, the Fe supplementation, which would induce erythropoiesis so increasing the number of erythrocytes available to be parasitized, did increase parasitaemia (i.e. the number of erythrocytes infected and the level of parasites per erythrocyte) and so the lack of increase in the disease suggests increased host defence.

\section{Zinc}

There are now a number of studies showing that $\mathrm{Zn}$ supplementation decreases the incidence of childhood diarrhoea (Ninh et al. 1996; Sazawal et al. 1996, 1998; Rosado et al. 1997; Roy et al. 1997, 1999; Ruel et al. 1997) and respiratory illness (Ninh et al. 1996; Sazawal et al. 1998; Roy et al. 1999). However, some studies fail to show benefit of $\mathrm{Zn}$ supplementation in respiratory disease (Bates et al. 1993; Rosada et al. 1997; Ruel et al. 1997; Lira et al. 1998). A recent placebo-controlled study in Mexico compared Zn supplementation with Zn plus other nutrients (including $\mathrm{Fe}$ ). $\mathrm{Zn}$ alone decreased the risk of developing diarrhoea whereas the $\mathrm{Zn}+$ other nutrients supplement increased the risk (Rosado et al. 1997). This may be due to the presence of $\mathrm{Fe}$, which has been shown to increase diarrhoea in young infants if added to milk (see earlier). In a recent study (Roy et al. 1999) Zn supplementation $(20 \mathrm{mg} / \mathrm{d})$ to malnourished children reduced diarrhoea-induced growth faltering.

Zn supplementation $(200 \mathrm{mg} / \mathrm{d})$ for $30 \mathrm{~d}$ reduced infectious disease morbidity in adults with AIDS (Mocchegiani et al. 1995). In contrast, those AIDS patients who had the highest intakes of $\mathrm{Zn}$ showed the most rapid progression of the disease (Tang et al. 1993) and the poorest survival (Tang et al. 1996).

\section{Concluding comments}

Health is multidimensional and, by the very nature of things, humans must share an environment in which large numbers of other organisms exist, some of which cause disease. The risk of infection can be limited by ensuring that the environment is structured to reduce the exposure to potentially harmful organisms and by enhancing the resistance of individuals and groups of people. The creation of a clean and safe environment, improved housing and a reduction in overcrowding, safe sexual practices and immunization programmes all contribute to decreasing the risk of infection and cross-infection. Enhanced nutrient status increases the likelihood of success of each of these approaches, generally by maintaining the effectiveness of the nonspecific barriers to infection (the skin, mucous membranes and bacteriostatic secretions), and ensuring a vigorous inflammatory and immune response. Protecting and maintaining the provision and availability of sufficient food of adequate quality is paramount and remains a central issue. Less apparent, but of equal significance, is the ability to ensure that unbalanced losses of nutrients from the body are minimized, most importantly by protecting against diarrhoeal 
disease, especially during early life. Diarrhoeal disease obviously limits the body's ability to absorb adequate nutrients from the diet, but more perniciously depletes the body of nutrients which are critically important for inflammatory and immune defences. Maternal education, appropriate child-rearing practices, the development of personal hygiene, the availability of plentiful amounts of water together with adequate water quality, and the ability to dispose of solid waste effectively remain fundamental imperatives of sound policies for the protection of the health of the public. Together, they are crucial for the cycle of infection and poor nutrition to be broken. Sustained effort is required to maintain established changes in behaviour.

Potential exposure to infectious agents is always present and in many areas of the world where it coexists with malnutrition it is readily translated into disease. Malnutrition diminishes immune function and so prevents the host from mounting an adequate protective response to infectious agents. In turn, infections alter nutrient status and can create a deficiency state. Thus, malnutrition and infection often act synergistically to increase morbidity and mortality, particularly among infants and children. The impact of vaccination programmes has been immense, but the global burden of malnutrition and infection remains vast. Fully understanding the impact of nutrients upon immune function and host resistance to infection, including interactions among nutrients, and fully understanding the impact of different infectious agents upon nutrient status remain key challenges to the scientific community. Putting this increased understanding into practice to relieve the developing world of this burden must be seen as a priority for action in the early years of the 21 st century.

\section{References}

Ahmed F, Barua S, Mohiduzzaman M, Shaheen N, Bhuyan MAH, Margetts BM \& Jackson AA (1993a) Interactions between growth and nutrient status in school-age children of urban Bangladesh. American Journal of Clinical Nutrition 58, 334-338.

Ahmed F, Jones DB \& Jackson AA (1990) The interaction of vitamin A deficiency and rotavirus infection in the mouse. British Journal of Nutrition 63, 363-373.

Ahmed F, Jones DB \& Jackson AA (1991) Effect of vitamin A deficiency on the immune response to epizootic diarrhoea of infant mice (EDIM) rotavirus infection in mice. British Journal of Nutrition 65, 475-485.

Ahmed F, Mohiduzzaman M \& Jackson AA (1993b) Vitamin A absorption in children with ascariasis. British Journal of Nutrition 69, 817-825.

Ahmed F, Zareen M, Khan MR, Banu CP, Haq MH \& Jackson AA (1998) Dietary pattern, nutrient intake and growth of adolescent school girls in urban Bangladesh. Public Health Nutrition 1, 83-92.

Alam N (1995) Predictors of diarrhoea in young Bangladeshi children. Journal of Tropical Pediatrics 41, 278-280.

Alam N, Wojtyniak B, Henry FJ \& Rahaman MM (1989) Mothers' personal and domestic hygiene and diarrhoea incidence in young children in rural Bangladesh. International Journal of Epidemiology 18, 242-247.

Ashworth A (2000) Low birth weight infants, infection and immunity. In Nutrition, Immunity and Infectious Diseases in Infants and Children [K Tontisirin and R Suskind, editors]. Basel: Karger (In the Press).

Aziz KM, Hoque BA, Hasan KZ, Patwary MY, Huttly SR, Rahaman MM \& Feachem RG (1990) Reduction in diarrhoeal diseases in children in rural Bangladesh by environmental and behavioural modifications. Transactions of the Royal Society of Tropical Medicine and Hygiene 84, 433-438.

Baggs RB \& Miller SA (1973) Nutritional iron deficiency as a determinant of host resistance in the rat. Journal of Nutrition 103, 1554-1560.

Bahl R, Bhandari N, Hambridge KM \& Bhan MK (1988) Plasma zinc as a predictor of diarrhoeal and respiratory morbidity in children in an urban slum setting. American Journal of Clinical Nutrition 68, 414S-417S.

Ballard TJ \& Neumann CG (1995) The effects of malnutrition, parental literacy and household crowding on acute lower respiratory infections in young Kenyan children. Journal of Tropical Pediatrics 41, 8-13.

Baqui AH, Sack RB, Black RE, Chowdhury HR, Yunnis M \& Siddique AK (1993) Cell-mediated immune deficiency and malnutrition are independent risk factors for persistent diarrhea in Bangladeshi children. American Journal of Clinical Nutrition 58, 543-548.

Barclay AJG, Foster A \& Sommer A (1986) Vitamin A supplements and mortality related to measles: a randomized clinical trial. British Medical Journal 294, 294-296. 
Barreto ML, Santos LMP, Assis AMO, Aranjo MP, Farenzena GG, Santos PA \& Fiaccone RL (1994) Effect of vitamin A supplementation on diarrhoea and acute lower respiratory tract infections in young children in Brazil. Lancet 344, $228-231$.

Barry DJM \& Reeve AW (1974) Iron and infection in the newborn. Lancet 184, 952-956.

Bates CJ, Evans PH, Dardenne M, Prentice A, Lunn PG, Northrop-Clewes CA, Hoare S, Cole TJ, Horan SJ, Longman SC, Stirling D \& Aggett PJ (1993) A trial of zinc supplementation in young rural Gambian children. British Journal of Nutrition 69, 243-255.

Baum MK, Shor-Posner G, Lai S, Zhang G, Fletcher MA, Sauberlich H \& Page JB (1997) High risk of mortality in HIV infection is associated with selenium deficiency. Journal of Acquired Immune Deficiency Syndromes and Human Retrovirology 15, 370-374.

Baum MK, Shor-Posner G, Lu Y, Rosner B, Sauberlich HE, Fletcher MA, Szapocznik J, Eisdorfer C, Buring JE \& Hennekens CH (1995) Micronutrients and HIV-1 disease progression. AIDS 9, 1051-1056.

Baynes R, Bexwoda W, Bothwell T, Khan Q \& Mansoor N (1986) The non-immune inflammatory response: serial changes in plasma iron, iron-binding capacity, lactoferrin, ferritin and C-reactive protein. Scandinavian Journal of Clinical Laboratory Investigation 46, 695-704.

Beisel WR (1972) Interrelated changes in host metabolism during generalized infectious illness. American Journal of Clinical Nutrition 25, 1254-1260.

Beisel WR (1975) Metabolic response to infection. Annual Review of Medicine 26, 9-20.

Bendich A (1993) Vitamin E and human immune functions. In Nutrition and Immunology, pp. 217-228 [DM Klurfeld, editor]. New York and London: Plenum Press.

Berger J, Schneider D, Dyck JL, Joseph A, Aplogan A, Galan P \& Hercberg S (1992) Iron-deficiency, cell-mediated immunity and infection among 6-36 month old children living in rural Togo. Nutrition Research 12, 39-49.

Bhandari N, Bhan MK \& Sazawal S (1994) Impact of massive dose of vitamin A given to preschool children with diarrhoea on subsequent respiratory and diarrhoeal morbidity. British Medical Journal 309, 1404-1407.

Birgens HS, Hansen NE, Karle H \& Kristensen LO (1983) Receptor binding of lactoferrin by human monocytes. British Journal of Haematology 54, 383-391.

Biswas R, Biswas AB, Manna B, Bhattacharybattacharya SK, Dey R \& Sarkar S (1994) Vitamin A supplementation in diarrhea and acute respiratory tract infections in children: a double-blind, placebo-controlled trial in a Calcutta slum community. European Journal of Epidemiology 10, 57-61.

Black RE, Brown KH \& Becker S (1984) Effects of diarrhea associated with specific enteropathogens on the growth of children in rural Bangladesh. Pediatrics 73, 799-805.

Bloem MW, Wedel M, Egger RJ, Speek AJ, Schrijver J, Saowakontha S \& Schreurs WHP (1990) Mild vitamin A deficiency and risk of respiratory tract diseases and diarrhea in preschool and school children in northeastern Thailand. American Journal of Epidemiology 131, 332-339.

Bloom BR \& Murray CJ (1992) Tuberculosis: commentary on a re-emergent killer. Science 257, 1055-1064.

Bresee JS, Fischer M, Dowell SF, Johnstone BD, Biggs VM, Levine RS, Lingappa JR, Keyserling HL, Petersen KM, Bak JR, Gary HE, Sowell AL, Rubens CE \& Anderson LJ (1996) Vitamin A therapy for children with respiratory syncytial virus infection: a multicentre trial in the United States. Pediatric Infectious Disease Journal 15, 777-782.

Briend A, Hasan KZ, Aziz KMA \& Hoque BA (1989) Are diarrhoea control programmes likely to reduce childhood malnutrition? Lancet ii, 319-322.

Brilliant LB, Pokhrel RP, Grasset NC, Lepkowski JM, Kolstad A, Hanks W, Pararajasegaram R, Brilliant GE, Gilbert S, Shrestha SR \& Kuo J (1985) Epidemiology of blindness in Nepal. Bulletin of the World Health Organization 63, $375-386$.

Briscoe J (1979) The quantitative effect of infection on the use of food by young children in poor countries. American Journal of Clinical Nutrition 32, 648-676.

Brock JH (1993) Iron and immunity. Journal of Nutritional Immunology 2, 47-106.

Brown K, Peerson JM, Kanashiro H, Lopez de Romana G \& Black R (1991) The relationship between diarrheal prevalence and growth of poor infants varies with their age and usual energy intake. FASEB Journal 5, A1079.

Brown KH, Black RE, Lopez de Romana G \& Creed de Kanashiro H (1989) Infant feeding practices and their relationship with diarrheal and other diseases in Huascar (Lima), Peru. Pediatrics 83, 31-40.

Brown KH, Stallings RY, de Kanashiro HC, Lopez de Romana G \& Black RE (1990) Effects of common illnesses on infants' energy intakes from breast milk and other foods during longitudinal community-based studies in Huascar (Lima), Peru. American Journal of Clinical Nutrition 52, 1005-1013.

Brunser O, Espinoza J, Araya M, Pacheco I \& Cruchet S (1993) Chronic iron intake and diarrhoeal disease in infants. A field study in a less-developed country. European Journal of Clinical Nutrition 47, 317-326.

Bullen JJ, Rogers HJ \& Leigh L (1972) Iron binding proteins in milk and resistance to Escherichia coli infection in infants. British Medical Bulletin 1, 69-75.

Butler JC, Havens PL, Sowell AL, Huff DL, Peterson DE, Day SE, Chusid MJ, Bennin RA, Circo R \& Davis JP (1993) Measles severity and serum retinol (vitamin A) concentration among children in the United States. Pediatrics 91, 1176-1181.

Campos FA, Flores H \& Underwood BA (1987) Effect of an infection on vitamin A status of children as measured by the relative dose response (RDR). American Journal of Clinical Nutrition 46, 91-94.

Cartwright GE, Lauritsen MA, Jones PJ, Merrill IM \& Wintrobe MM (1946) The anemia of infection. Journal of Clinical Investigation 25, 65-80. 
Castaldo A, Tarallo L, Palomba E, Albano F, Russo S, Zuin G, Buffardi F \& Guarino A (1996) Iron deficiency and intestinal malabsorption in HIV disease. Journal of Pediatric Gastroenterology and Nutrition 22, 359-363.

Castillo-Duran C, Vial P \& Uauy R (1988) Trace element and mineral balance during acute diarrhea in infants. Journal of Pediatrics 113, 452-457.

Chandra RK (1975) Reduced secretory antibody response to live attenuated measles and poliovirus vaccines in malnourished children. British Medical Journal 2, 583-585.

Chandra RK (1979) Serum thymic hormone activity in protein-energy malnutrition. Clinical and Experimental Immunology 38, 228-230.

Chandra RK (1983a) Nutrition, immunity and infection. Present knowledge and future directions. Lancet i, $688-691$.

Chandra RK (1983b) Numerical and functional deficiency in T helper cells in protein-energy malnutrition. Clinical and Experimental Immunology 51, 126-132.

Chandra RK (1984) Excessive intake of zinc impairs immune responses. Journal of the American Medical Association 252, $1443-1446$.

Chandra RK (1991) 1990 McCollum Award Lecture. Nutrition and immunity: lessons from the past and new insights into the future. American Journal of Clinical Nutrition 53, 1087-1101.

Chandra RK (2000) The effect of iron and trace element deficiencies and supplementation on infection and immune response. In Nutrition, Immunity and Infectious Diseases in Infants and Children [K Tontisirin and R Suskind, editors]. Basel: Karger (In the Press).

Chandra RK, Chandra S \& Gupta S (1984) Antibody affinity and immune complexes after immunization with tetanus toxoid in protein-energy malnutrition. American Journal of Clinical Nutrition 40, 131-134.

Chandra RK, Gupta S \& Singh H (1982) Inducer and suppressor T cell subsets in protein-energy malnutrition. Nutrition Research 2, 21-26.

Chwang LC, Soemantri AG \& Pollitt E (1988) Iron supplementation and physical growth in rural Indonesian children. American Journal of Clinical Nutrition 47, 496-501.

Condon-Paolini D, Cravioto J, Johnston FE, De Licardie ER \& Scholi TO (1977) Morbidity and growth of infants and young children in a rural Mexican village. American Journal of Public Health 67, 651-656.

Coutsoudis A, Bobat RA, Coovadia HM, Kuhn L, Tsai WY \& Stein ZA (1995) The effects of vitamin A supplementation on the morbidity of childen born to HIV-infected women. American Journal of Public Health 85, 1076-1081.

Coutsoudis A, Broughton M \& Coovadia HM (1991) Vitamin A supplementation reduces measles morbidity in young African children: a randomized, placebo-controlled, double-blind trial. American Journal of Clinical Nutrition 54, $890-895$.

Coutsoudis A, Pillay K, Spooner E, Kuhn L \& Coovadia HM (1999) Randomized trial testing the effect of vitamin A supplementation on pregnancy outcomes and early mother-to-child transmission in Durban, South Africa. South African Vitamin A Study Group. AIDS 13, 1517-1524.

Das BS, Thurnham DI, Patnaik JK, Das DB, Satpathy R \& Bose TK (1990) Increased plasma lipid peroxidation in riboflavin deficient, malaria infected children. American Journal of Clinical Nutrition 51, 859-863.

Daulaire NMP, Starbuck ES, Houston RM, Church MS, Stukel TA \& Pandey MR (1992) Childhood mortality after a high dose of vitamin A in a high risk population. British Medical Journal 304, 207-210.

DeSole G, Belay Y \& Zegeye B (1987) Vitamin A deficiency in southern Ethiopia. American Journal of Clinical Nutrition 45, 780-784.

Dibley MJ, Sadjimin T, Kjolhede CL \& Moulton LH (1996) Vitamin A supplementation fails to reduce incidence of acute respiratory illness and diarrhea in preschool-age Indonesian children. Journal of Nutrition 126, 434442.

Dowell SF, Papic Z, Bresee JS, Larranaga C, Mendez M, Sowell AL, Gary HE, Anderson LJ \& Avendano LF (1996) Treatment of respiratory syncytial virus infection with vitamin A: a randomized, placebo-controlled trial in Santiago, Chile. Pediatric Infectious Disease Journal 15, 782-786.

DuBois EF (1936) Basal Metabolism in Health and Disease. Philadelphia, PA: Lea \& Febiger.

Duggan MB, Alwar J \& Milner RD (1986) The nutritional cost of measles in Africa. Archives of Disease in Childhood 61, $61-66$.

Edirisinghe JS, Fern EB \& Targett GAT (1981) Dietary suppression of rodent malaria. Transactions of the Royal Society of Tropical Medicine and Hygiene 75, 591-593.

Ehrenpreis ED, Carlson SJ, Boorstein HL \& Craig RM (1994) Malabsorption and deficiency of vitamin B12 in HIVinfected patients with chronic diarrhea. Digestive Diseases and Sciences 39, 2159-2162.

Ekanem EE, Akitoye CO \& Adedeji OT (1991) Food hygiene behaviour and childhood diarrhoea in Lagos, Nigeria: a case-control study. Journal of Diarrhoeal Diseases Research 9, 219-226.

English RM, Badcock JC, Giay T, Ngu T, Waters AM \& Bennett SA (1997) Effect of nutrition improvement project on morbidity from infectious diseases in preschool children in Vietnam: comparison with control commune. British Medical Journal 315, $1122-1125$.

Failla ML \& Hopkins RG (1998) Is low copper status immunosuppressive? Nutrition Reviews 56, S59-S64.

Farrell PM, Zachman RD \& Gutcher GR (1985) Fat soluble vitamins A, E and K in the premature infant. In Vitamin and Mineral Requirements in Preterm Infants, pp. 63-98 [RC Tsang, editor]. New York, NY: Marcel Dekker.

Fawzi WW, Chalmers TC, Herrera MG \& Mosteller F (1993) Vitamin A supplementation and childhood mortality. A meta-analysis. JAMA 269, 898-903. 
Fawzi WW, Msamanga GI, Spiegelman D, Urassa EJ, McGrath N, McGrath D, Mwakagile D, Antelman G, Mbise R, Herrera G, Kapiga S, Willett W \& Hunter DJ (1998) Randomized trial of effects of vitamin supplements on pregnancy outcomes and T cell counts in HIV-1-infected women in Tanzania. Lancet 351, 1477-1482.

Fevang P, Saav H \& Hostmark AT (1995) Dietary fish oil and long-term malaria protection in mice. Lipids 30, $437-441$.

Food and Agriculture Organization (1996) Sixth World Survey. Rome: Food and Agriculture Organization.

Fraker PJ, King LE, Garvy BA \& Medina CA (1993) The immunopathology of zinc deficiency in humans and rodents: a possible role for programmed cell death. In Nutrition and Immunology, pp. 267-283 [DM Klurfeld, editor]. New York and London: Plenum Press.

Ghana VAST Study Team (1993) Vitamin A supplementation in northern Ghana: effects on clinical attendances, hospital admissions, and child mortality. Lancet 342, 7-12.

Glasziou PP \& Mackerras DEM (1993) Vitamin A supplementation in infectious disease: a meta-analysis. British Medical Journal 306, 366-370.

Golden MHN, Golden BE, Harland PSEG \& Jackson AA (1978) Zinc and immunocompetence in protein-energy malnutrition. Lancet $\mathbf{i}, 1226-1228$.

Golden MHN, Jackson AA \& Golden BE (1977) Effect of zinc on thymus of recently malnourished children. Lancet ii, $1057-1059$.

Golding J, Emmett PM \& Rogers IS (1997a) Gastroenteritis, diarrhoea and breast feeding. Early Human Development 49, S83-S103.

Golding J, Emmett PM \& Rogers IS (1997b) Does breast feeding protect against non-gastric infections? Early Human Development 49, S105-S120.

Golding J, Emmett PM \& Rogers IS (1997c) Breast feeding and infant mortality. Early Human Development 49, S143S 155 .

Gopalan C, Swaminathan MC, Kumari VKK, Rao DH \& Vijayaraghavan K (1973) Effect of calorie supplementation on growth of undernourished children. American Journal of Clinical Nutrition 26, 563-566.

Gorter AC, Sandiford P, Pauw J, Morales P, Perez RM \& Alberts H (1998) Hygiene behaviour in rural Nicaragua in relation to diarrhoea. International Journal of Epidemiology 27, 1090-1100.

Graham NMH, Sorensen D, Odaka N, Brookmeyer R, Chan D, Willett WC, Morris JS \& Shah AJ (1991) Relationship of serum copper and zinc levels on HIV-1 seropositivity and progression to AIDS. Journal of Acquired Immune Deficiency Syndromes 4, 976-980.

Greenberg BL, Semba RD, Vink PE, Farley JJ, Sivapalasingam M, Steketee RW, Thea DM \& Schoenbaum EE (1997) Vitamin A deficiency and maternal-infant transmission of HIV in two metropolitan areas in the United States. AIDS 11, 325-332.

Grimble RF (1999) Nutritional influences on inflammation. In Inflammatory Bowel Diseases, pp. 63-81 [BR Bistrian and JA Walker-Smith, editors]. Basel: Karger.

Gross R \& Schultink W (1997) Micronutrient deficiencies in urban Indonesia. Archivos Latinoamericanos de Nutricion 47, 50-53.

Gujral S, Abbi R \& Gopaldas T (1993) Xerophthalmia, vitamin A supplementation and morbidity in children. Journal of Tropical Pediatrics 39, 89-92.

Haggerty PA, Muladi K, Kirkwood BR, Ashworth A \& Manunebo M (1994) Community-based hygiene education to reduce diarrhoeal disease in rural Zaire: impact of the intervention on diarrhoeal morbidity. International Journal of Epidemiology 23, 1050-1059.

Harriman GR, Smith PD, Horne MK, Fox CH, Koenig S, Lack EE, Lane HC \& Fauci AS (1989) Vitamin B 12 malabsorption in patients with acquired immunodeficiency syndrome. Archives of Internal Medicine 149, 2039-2041.

Hasselbalch H, Jeppesen DL, Engelmann MDM, Michaelsen KF \& Nielsen MB (1996) Decreased thymus size in formula-fed infants compared with breastfed infants. Acta Paediatrica 85, 1029-1032.

Henry FJ, Patwary Y, Huttly SR \& Aziz KM (1990) Bacterial contamination of weaning foods and drinking water in rural Bangladesh. Epidemiology and Infection 104, 79-85.

Henry FJ \& Rahim Z (1990) Transmission of diarrhoea in two crowded areas with different sanitary facilities in Dhaka, Bangladesh. Journal of Tropical Medicine and Hygiene 93, 121-126.

Heresi G, Pizarro F, Olivares M, Cayazzo M, Hertramp E, Walter T, Murphy JR \& Stekel A (1995) Effect of supplementation with iron-fortified milk on incidence of diarrhea and respiratory-infection in urban resident families. Scandinavian Journal of Infectious Diseases 27, 385-389.

Herrera MG, Nestel P, El Amin A, Fawzi WW, Mohamed KA \& Weld L (1992) Vitamin A supplementation and child survival. Lancet 340, 267-271.

Hlaing T (1993) Ascariasis and childhood malnutrition. Parasitology 107, S125-S136.

Howie PW, Forsyth JS, Ogston SA, Clark A \& Florey C deV (1990) Protective effect of breast feeding against infection. British Medical Journal 300, 11-16.

Humphrey JH, Agoestina T, Wu L, Usman A, Nurachim M, Subardja D, Hidayat S, Tielsch J, West KP \& Sommer A (1996) Impact of neonatal vitamin A supplementation on infant morbidity and mortality. Journal of Pediatrics 128, 489-496.

Hussey GD \& Klein H (1990) A randomized, controlled trial of vitamin A in children with severe measles. New England Journal of Medicine 323, 160-164.

Jackson AA \& Golden MHN (1978) The human rumen. Lancet ii, 764-767. 
John GC, Nduati RW, Mbori-Ngacha D, Overbaugh J, Welch M, Richardson BA, Ndinya- Achola J, Bwayo J, Kreiger J, Onyango F \& Kreiss JK (1997) Genital shedding of human immunodeficiency virus type 1 DNA during pregnancy: association with immunosuppression, abnormal cervical or vaginal discharge, and severe vitamin A deficiency. Journal of Infectious Diseases 175, 57-62.

Kelly P, Musonda R, Kafwembe E, Kietano L, Keane E \& Farthing M (1999) Micronutrient supplementation in the AIDS-diarrhoea wasting syndrome in Zambia: a randomized controlled trial. AIDS 13, 495-500.

Kennedy N, Ramsay A, Uiso L, Gutman J, Ngoni FI \& Gillespie SH (1996) Nutritional status and weight gain in patients with pulmonary tuberculosis in Tanzania. Transactions of the Royal Society of Tropical Medicine and Hygiene 90, $162-166$.

Keusch GT \& Farthing MJG (1986) Nutrition and infection. Annual Review of Nutrition 6, 131-154.

Kjolhede CL, Chew FJ, Gadomski AM \& Marroquin DP (1995) Clinical trial of vitamin A as adjuvant treatment for lower respiratory tract infections. Journal of Pediatrics 126, 807-812.

Koch J, Garcia-Shelton YL, Neal EA, Chan MF, Weaver KE \& Cello JP (1996) Steatorrhea: a common manifestation in patients with HIV/AIDS. Nutrition 12, 507-510.

Kolsteren P, Rahman SR, Hilderbrand K \& Diniz A (1999) Treatment for iron deficiency anaemia with a combined supplementation of iron, vitamin A and zinc in women in Dinajpur, Bangladesh. European Journal of Clinical Nutrition 53, $102-106$.

Koster FT, Palmer DL, Chakraborty J, Jackson T \& Curlin GC (1987) Cellular immune competence and diarrheal morbidity in malnourished Bangladeshi children: a prospective field study. American Journal of Clinical Nutrition 46, $543-548$.

Kuvibidila S, Yu L, Ode D \& Warrier RP (1993) The immune response in protein-energy malnutrition and single nutrient deficiencies. In Nutrition and Immunology, pp. 121-155 [DM Klurfeld, editor]. New York and London: Plenum Press.

Levander OA, Fontela R, Morris VC \& Ager AL (1995) Protection against murine cerebral malaria by dietary-induced oxidative stress. Journal of Parasitology 81, 99-103.

Leyton GB (1946) Effects of slow starvation. Lancet 251, 73-79.

Lie C, Ying C, En-Lin W, Brun T \& Geissler C (1993) Impact of large-dose vitamin A supplementation on childhood diarrhoea, respiratory disease and growth. European Journal of Clinical Nutrition 47, 88-96.

Lira PI, Ashworth A \& Morris SS (1998) Effect of zinc supplementation on the morbidity, immune function and growth of low birth weight full-term infants in northeast Brazil. American Journal of Clinical Nutrition 69, 418S-424S.

Lopez A (1997) Global burden of disease study. ACC/SCN News 14, 42-43.

Lucas SB, De Cock KM, Hounnou A, Peacock C, Diomande M, Honde M, Beaumel A, Kestens L \& Kadio A (1994) Contribution of tuberculosis to Slim Disease in Africa. British Medical Journal 308, 1531-1533.

Lunn PG, Northrup-Clewes CA \& Downes RM (1991) Intestinal permeability, mucosal injury, and growth faltering in Gambian infants. Lancet 338, 907-910.

Lutter CK, Mora JO, Habiicht JP, Rasmussen KM, Robson DS, Sellers SG, Super CM \& Herrera MG (1989) Nutritional supplementation: effects on child stunting because of diarrhea. American Journal of Clinical Nutrition 50, 1-8.

Macallan DC (1998) Metabolic abnormalities and wasting in human immunodeficiency virus infection. Proceedings of the Nutrition Society 57, 373-380.

Macallan DC, Noble C, Baldwin C, Jebb SA, Prentice AM, Coward WA, Sawyer MB, McManus TJ \& Griffin GE (1995) Energy expenditure and wasting in Human Immunodeficiency Virus infection. New England Journal of Medicine 333, 83-88.

McFarlane H, Reddy S, Adcok KJ, Adeshina H, Cooke AR \& Akene J (1970) Immunity, transferrin and survival in kwashiorkor. British Medical Journal 4, 268-270.

Markowitz LE, Nzilambi N, Driskell WJ, Sension MG, Rovira EZ, Nieburg P \& Ryder RW (1989) Vitamin A levels and mortality among hospitalized measles patients, Kinshasa, Zaire. Journal of Tropical Pediatrics 35, $109-112$.

Martorell R, Habicht JP, Yarbrough C, Lechtig A, Klein RE \& Western KA (1975) Acute morbidity and physical growth in rural Guatemalan children. American Journal of Diseases in Children 129, 1296-1301.

Martorell R, Yarbrough C, Yarbrough S \& Klein RE (1980) The impact of ordinary illnesses on the dietary intakes of malnourished children. American Journal of Clinical Nutrition 33, 345-350.

Mata L (1992) Diarrheal disease as a cause of malnutrition. American Journal of Tropical Medicine and Hygiene 47, $16-27$.

Mata LJ, Kromal RA, Urrutia JJ \& Garcia B (1977) Effect of infection on food intake and the nutritional state: perspectives as viewed from the village. American Journal of Clinical Nutrition 30, 1215-1227.

Melchior JC, Raguin G, Boulier A, Bouvet E, Rigaud D, Matheron S, Casalino E, Vilde JL \& Vachon F (1993) Resting energy expenditure in human immunodeficiency virus-infected patients: comparison between patients with and without secondary infections. American Journal of Clinical Nutrition 57, 614-619.

Menendez C, Kahigwa E, Hirt R, Vounatsou P, Aponte JJ, Font F, Acosta CJ, Schellenberg DM, Galindo CM, Kimario J, Urassa H, Brabin B, Smith TA, Kitua AY, Tanner M \& Alonso PL (1997) Randomised placebo-controlled trial of iron supplementatation and malaria chemoprophylaxis for prevention of severe anaemia and malaria in Tanzanian infants. Lancet 350, 844-850.

Miller ARO, Griffin GE, Batman P, Farquar C, Foster SM, Pinching AJ \& Harris JRW (1988) Jejunal mucosal architecture and fat absorption in male homosexuals infected with human immunodeficiency virus. Quarterly Journal of Medicine 69, 1009-1019. 
Miller TL, Olav EJ, Martin SR, Cooper ER, McIntosh K \& Winter HS (1991) Malnutrition and carbohydrate malabsorption in children with vertically transmitted human immunodeficiency virus 1 infection. Gastroenterology 100, 1296-1302.

Milton RC, Reddy V \& Naidu AN (1987) Mild vitamin A deficiency and childhood morbidity — an Indian experience. American Journal of Clinical Nutrition 46, 827-829.

Mitra AK, Akramuzzaman SM, Fuchs GJ, Rahman MM \& Mahalanabis D (1997) Long-term oral supplementation with iron is not harmful for young children in a poor community of Bangladesh. Journal of Nutrition 127, 1451-1455.

Mocchegiani E, Veccia S, Ancarani F, Scalise G \& Fabris N (1995) Benefit of oral zinc supplementation as an adjunct to zidovudine (AZT) therapy against opportunistic infections in AIDS. International Journal of Immunopharmacology 17, 719-727.

Molla AM, Molla A, Sarker SA, Khatoon M \& Rahaman MM (1983a) Effects of acute diarrhea on absorption of macronutrients during disease and recovery. In Diarrhea and Malnutrition: Interactions, Mechanisms and Interventions, pp. 143-154 [LD Chen, editor]. New York, NY: Plenum Press.

Molla AM, Molla A, Sarker SA \& Rahaman MM (1983b) Food intake during and after recovery from diarrhea in children. In Diarrhea and Malnutrition: Interactions, Mechanisms and Interventions, pp. 113-123 [LD Chen, editor]. New York, NY: Plenum Press.

Molyneux DH (1997) Control of parasites, parasitic infections and parasitic diseases. In Topley and Wilson's Microbiology and Microbial Infections, vol. 5, pp. 85-112 [FEF Cox, JP Kreier and D Wakelin, editors]. London: Arnold.

Morris SS, Cousens SN, Kirkwood BR, Arthur P \& Ross DA (1996) Is prevalence of diarrhea a better predictor of subsequent mortality and weight gain than diarrhea incidence? American Journal of Epidemiology 144, $582-588$.

Mostad SB, Overbaugh J, De Vange DM, Welch MJ, Chohan B, Mandaliya K, Nyange P, Martin HL Jr, Ndinya-Achola J, Bwayo JJ \& Kreiss JK (1997) Hormonal contraception, vitamin A deficiency, and other risk factors for shedding HIV-1 infected cells from the cervix and vagina. Lancet 350, 922-927.

Moy RJD, Marshall TF de C, Choto RGAB, McNeish AS \& Booth IW (1994) Diarrhoea and growth faltering in rural Zimbabwe. European Journal of Clinical Nutrition 48, 810-821.

Muhilal H, Permeisih D, Idjradinata YR, Muherdiyantiningsih \& Karyadi D (1988) Vitamin A-fortified monosodium glutamate and health, growth and survival of children: a controlled field trial. American Journal of Clinical Nutrition 48, 1271-1276.

Murray C \& Lopez A (1996) The Global Burden of Disease. Cambridge, MA: Harvard School of Public Health.

Murray MJ, Murray AB, Murray MB \& Murray NJ (1978a) Diet and cerebral malaria: the effect of famine and refeeding. American Journal of Clinical Nutrition 31, 57-61.

Murray MJ, Murray AB, Murray MB \& Murray NJ (1978b) The adverse effect of iron repletion on the course of certain infections. British Medical Journal ii, 1113-1115.

Nacul LC, Kirkwood BR, Arthur P, Morris SS, Magalhaes M \& Fink MC (1997) Randomized, double-blind placebo controlled trial of efficacy of vitamin A treatment in non-measles childhood pneumonia. British Medical Journal 315, $505-510$.

Nduati RW, John GC, Richardson BA, Overbaugh J, Welch M, Ndinya-Achola J, Moses S, Holmes K, Onyango F \& Kreiss JK (1995) Human immunodeficiency virus type 1-infected cells in breast milk: association with immunosuppression and vitamin A deficiency. Journal of Infectious Diseases 172, 1461-1468.

Ninh NX, Thissen J-P, Collette L, Gerrard G, Khoi HH \& Ketelslegers JM (1996) Zinc supplementation increases growth and circulating insulin-like growth factor (IGF-1) in growth retarded Vietnamese children. American Journal of Clinical Nutrition 63, 514-519.

Ogaro FO, Orinda VA, Onyango FE \& Black RE (1993) Effect of vitamin A on diarrhoeal and respiratory complications of measles. Tropical and Geographical Medicine 45, 283-286.

Onwubalili JK (1988) Malnutrition among tuberculosis patients in Harrow, England. European Journal of Clinical Nutrition 42, 363-366.

Oppenheimer SJ, Gibson FD, MacFarlane SB, Moody JB, Harrison C, Spencer A \& Bunari O (1986) Iron supplementation increases prevalence and effects of malaria: report on clinical studies in Papua New Guinea. Transactions of the Royal Society of Tropical Medicine and Hygiene 80, 603-612.

Pawlowski ZS, Schad GA \& Stott GJ (1991) Hookworm Infection and Anaemia. Geneva: World Health Organization.

Payne SM \& Finkelstein RA (1978) The critical role of iron in host-bacterial interactions. Journal of Clinical Investigation 61, 1428-1440.

Pinnock CB, Douglas RM \& Badcock NR (1986) Vitamin A status in children who are prone to respiratory tract infections. Australian Paediatric Journal 22, 95-99.

Powanda MC (1977) Changes in body balances of nitrogen and other key nutrients: description and underlying mechanisms. American Journal of Clinical Nutrition 30, 1254-1268.

Powers HJ (1993) Micronutrient deficiencies in the preterm neonate. Proceedings of the Nutrition Society 52, $285-$ 291.

Prohaska JR \& Failla ML (1993) Copper and immunity. In Nutrition and Immunology, pp. 309-332 [DM Klurfeld, editor]. New York and London: Plenum Press.

Rahman MM, Mahalanabis D, Alvarez JO, Wahed MA, Islam MA, Habte D \& Khaled MA (1996) Acute respiratory infections prevent improvement of vitamin A status in young infants supplemented with vitamin A. Journal of Nutrition 126, 628-633. 
Rahmathullah L, Underwood BA, Thulasiraj RD \& Milton RC (1991) Diarrhea, respiratory infections, and growth are not affected by a weekly low-dose vitamin A supplement: a masked, controlled field trial in children in southern India. American Journal of Clinical Nutrition 54, 568-577.

Rahmathullah L, Underwood BA, Thulasiraj RD, Milton RC, Ramaswamy K, Rahmathulla R \& Babu G (1990) Reduced mortality among children in Southern India receiving a small weekly dose of vitamin A. New England Journal of Medicine 323, 929-935.

Rajagopalan S \& Yoshikawa TT (1998) Tuberculosis in the elderly. Baillieres Clinical Infectious Diseases 5, $105-118$.

Ramakrishnan U, Latham MC, Abel R \& Frongillo EA Jr (1995) Vitamin A supplementation and morbidity among preschool children in South India. American Journal of Clinical Nutrition 61, 1295-1303.

Ramdath DD, Simeon DT, Wong MS \& Grantham-McGregor SM (1995) Iron status of school children with varying intensities of Trichuris trichiura infection. Parasitology 110, 347-351.

Reddy V, Bhaskaram P, Raghuramulu N, Milton RC, Rao V, Madhusudan J \& Krishna KVR (1986) Relationship between measles, malnutrition, and blindness: a prospective study in Indian children. American Journal of Clinical Nutrition 44, 924-930.

Rosado JL, Lopez P, Munoz E, Martinez H \& Allen LH (1997) Zinc supplementation reduced morbidity, but neither zinc nor iron supplementation affected growth or body composition of Mexican pre-schoolers. American Journal of Clinical Nutrition 65, 13-19.

Rowland MG, Cole TJ \& Whitehead RG (1977) A quantitative study into the role of infection in determining nutritional status in Gambian village children. British Journal of Nutrition 37, 441-450.

Roy SK, Tomkins AM, Akramuzzaman SM, Behrens RH, Haider R, Mahalanabis D \& Fuchs G (1997) Randomized controlled trial of zinc supplementation in malnourished Bangladeshi children with diarrhoea. Archives of Disease in Childhood 77, 196-200.

Roy SK, Tomkins AM, Haider R, Behra RH, Akramuzzaman SM, Mahalanabis D \& Fuchs GJ (1999) Impact of zinc supplementation on subsequent growth and morbidity in Bangladeshi children with acute diarrhoea. European Journal of Clinical Nutrition 53, 529-534.

Ruel MT, Rivera JA, Santizo M-C, Lonnerdal B \& Brown KH (1997) Impact of zinc supplementation on morbidity from diarrhoea and respiratory infections among rural Guatemalan children. Pediatrics 99, 808-813.

Saavedra JM, Henderson RA, Perman JA, Hutton N, Livingstone RA \& Yolken RH (1995) Longitudinal assessment of growth in children born to mothers with human immunodeficiency virus infection. Archives of Pediatrics and Adolescent Medicine 149, 497-502.

Sazawal S, Black RE, Bhan MK, Jalla S, Bhandari N, Sinha A \& Majumdar S (1996) Zinc supplementation reduces the incidence of persistent diarrhea and dysentery among low socioeconomic children in India. Journal of Nutrition 126, $443-450$.

Sazawal S, Black RE, Jalla S, Mazumdar S, Sinha A \& Bhan MK (1998) Zinc supplementation reduces the incidence of acute respiratory infections in infants and preschool children: a double-blind, controlled trial. Pediatrics 102, 1-5.

Scrimshaw NS, Taylor CE \& Gordon JE (1959) Interaction of nutrition and infection. American Journal of Medical Science 237, 367-403.

Scrimshaw NS, Taylor CE \& Gordon JE (1968) Interactions of Nutrition and Infection. Geneva: World Health Organization.

Scrimshaw NS \& SanGiovanni JP (1997) Synergism of nutrition, infection and immunity: an overview. American Journal of Clinical Nutrition 66, 464S-477S.

Semba RD (1997) Vitamin A and human immunodeficiency virus infection. Proceedings of the Nutrition Society 56, $459-469$.

Semba RD (1998) The role of vitamin A and related retinoids in immune function. Nutrition Reviews 56, S38-S48.

Semba RD, Graham NMH, Caiaffa WT, Margolick JB, Clement L \& Vlahov D (1993) Increased mortality associated with vitamin A deficiency during human immunodeficiency virus type 1 infection. Archives of Internal Medicine 153, $2149-2154$.

Semba RD, Lyles C, Margolick J, Caiaffa WT, Farzadegan H, Cohn S \& Vlahov D (1998) Vitamin A supplementation and human immunodeficiency virus load in injection drug users. Journal of Infectious Diseases 177, 611-616.

Semba RD, Miotti P, Chiphangwi JD, Henderson R, Dallabetta G, Yang LP \& Hoover DR (1997) Maternal vitamin A deficiency and child growth failure during human immunodeficiency virus infection. Journal of Acquired Immune Deficiency Syndromes and Human Retrovirology 14, 219-222.

Semba RD, Miotti PG, Chiphangwi JD, Shah A, Canner J, Dallabetta G \& Hoover DR (1994) Maternal vitamin A deficiency and mother-to-child transmission of HIV-1. Lancet 343, $1593-1597$.

Semba RD \& Tang AM (1999) Micronutrients and the pathogenesis of human immunodeficiency virus infection. British Journal of Nutrition 81, 181-189.

Sempertegui F, Estrella B, Camaniero V, Betancourt V, Izurieta R, Ortiz W, Faillo E, Troya S, Rodriguez A \& Griffiths JK (1999) The beneficial effects of weekly low-dose vitamin A supplementation on acute lower respiratory infections and diarrhea in Ecuadorian children. Pediatrics 104, E11-E17.

Shankar AH \& Prasad AS (1998) Zinc and immune function: the biological basis of altered resistance to infection. American Journal of Clinical Nutrition 68, S447-S463.

Shenai JP, Kennedy KA, Chytil F \& Stahlman MT (1987) Clinical trial of vitamin A supplementation in infants susceptible to bronchopulmonary dysplasia. Journal of Pediatrics 111, 269-277. 
Sherman AR \& Spear AT (1993) Iron and immunity. In Nutrition and Immunology, pp. 285-307 [DM Klurfeld, editor]. New York and London: Plenum Press.

Shi HN, Scott ME, Stevenson MM \& Koski KG (1998) Energy restriction and zinc deficiency impair the functions of murine T cells and antigen-presenting cells during gastrointestinal nematode infection. Journal of Nutrition 128, 20 27.

Siegel BV (1993) Vitamin C and the immune response in health and disease. In Nutrition and Immunology, pp. 167196 [DM Klurfeld, editor]. New York and London: Plenum Press.

Sinha DP \& Bang FB (1976) The effect of massive doses of vitamin A on the signs of vitamin A deficiency in preschool children. American Journal of Clinical Nutrition 29, 110-115.

Sivakumar B \& Reddy V (1972) Absorption of labelled vitamin A in children during infection. British Journal of Nutrition 27, 299-304.

Sivakumar B \& Reddy V (1975) Absorption of vitamin A in children with ascariasis. Journal of Tropical Medicine and Hygiene 78, 114-115.

Snow RW, Byass P, Shenton FC \& Greenwood BM (1991) The relationship between anthropomorphic measurements and measurements of iron status and susceptibility to malaria in Gambian children. Transactions of the Royal Society of Tropical Medicine and Hygiene 85, 584-589.

Solon FS, Popkin BM, Fernandez TL \& Latham MC (1978) Vitamin A deficiency in the Philippines: a study of xerophthalmia in Cebu. American Journal of Clinical Nutrition 31, 360-368.

Sommer A, Katz J \& Tarwotjo I (1984) Increased risk of respiratory disease and diarrhea in children with pre-existing mild vitamin A deficiency. American Journal of Clinical Nutrition 40, 1090-1095.

Sommer A, Tarwotjo I, Djunaedi E, West KP Jr, Loeden AA, Tilden R, Mele L \& the Aceh Study Group (1986) Impact of vitamin A supplementation on childhood mortality. A randomised controlled community trial. Lancet i, 11691173.

Sommer A, Tarwotjo I, Hussaini G \& Susanto G (1983) Increased mortality in children with mild vitamin A deficiency. Lancet ii, $585-588$.

Sommer A, Tarwotjo I \& Katz J (1987) Increased risk of xerophthalmia following diarrhea and respiratory disease. American Journal of Clinical Nutrition 45, 977-980.

Stabel JR \& Spears JW (1993) Role of selenium in immune responsiveness and disease resistance. In Nutrition and Immunology, pp. 333-356 [DM Klurfeld, editor]. New York and London: Plenum Press.

Stanton BF, Clemens JD, Wojtyniak B \& Khair T (1986) Risk factors for developing mild nutritional blindness in urban Bangladesh. American Journal of Diseases of Children 140, 584-588.

Stephensen CB, Alvarez JO, Kohatsu J, Hardmeier R, Kennedy JI Jr \& Gammon RB Jr (1994) Vitamin A is excreted in the urine during acute infection. American Journal of Clinical Nutrition 60, 388-392.

Stephenson LS (1987) The impact of helminth infections on human nutrition: Schistosomes and soil-transmitted helminths. New York, NY: Taylor \& Francis.

Tang AM, Graham NMH, Kirby AJ, McCall LD \& Saah AJ (1993) Dietary micronutrient intake and risk for progression to acquired immunodeficiency syndrome (AIDS) in human-immunodeficiency-virus type-1 (HIV-1) infected homosexual men. American Journal of Epidemiology 138, 937-961.

Tang AM, Graham NMH \& Saah AJ (1996) Effects of micronutrient intake on survival in human immunodeficiency virus type 1 infection. American Journal of Epidemiology 143, 1244-1256.

Taylor DW, Levander OA, Krishna VR, Evans CB, Morris VC \& Barta JR (1997) Vitamin E deficient diets enriched with fish oil suppress lethal Plasmodium yoelii infections in athymic and SCID/bg mice. Infection and Immunity $\mathbf{6 5}$, 197-202.

The Vitamin A and Pneumonia Working Group (1995) Potential interventions for the prevention of childhood pneumonia in developing countries: a meta-analysis of data from field trials to assess the impact of vitamin A supplementation on pneumonia morbidity and mortality. Bulletin of the World Health Organization 73, 609-619.

Thuma PE, Mabeza GF, Biemba G, Bhat GJ, McLaren CE, Moyo VM, Zulu S, Khumalo H, Mabeza P, Mhango A, Parry D, Poltera AA, Brittenham GM \& Gordenk VR (1998) Effect of iron chelation therapy on mortality in Zambian children with cerebral malaria. Transactions of the Royal Society of Tropical Medicine and Hygiene 92, 214-218.

Tielsch JM, West KP, Katz J, Chirambo MC, Schwab L, Johnson GJ, Tizazu T, Swarwood J \& Sommer A (1986) Prevalence and severity of xerophthalmia in southern Malawi. American Journal of Epidemiology 124, 561-568.

Tompkins A \& Watson F (1993) Malnutrition and Infection - A Review. ACC/SCN State-of-the-Art Series, Nutrition Policy Document no. 5.

United Nations (1994) Development Programme Human Development Report. New York, NY: United Nations.

United Nations (1996) Update on the Nutrition Situation. Summary of Results for the 3rd Report on the World Nutrition Situation. New York, NY: United Nations.

United Nations International Children's Emergency Fund (1996) State of the World's Children. Oxford: Oxford University Press.

Victora CG, Barros FC, Kirkwood BR \& Vaughan JP (1990) Pneumonia, diarrhea, and growth in the first 4 y of life: a longitudinal study of 5914 urban Brazilian children. American Journal of Clinical Nutrition 52, 391-396.

Vijayaraghavan K, Radhalah G, Prakasam BS, Sarma KVR \& Reddy V (1990) Effect of massive dose vitamin A on morbidity and mortality in Indian children. Lancet ii, 1342-1345.

Vyas D \& Chandra RK (1983) Thymic factor activity, lymphocyte stimulation response and antibody-forming cells in copper deficiency. Nutrition Research 3, 343-350. 
West KP Jr, Pokhrel RP, Katz J, LeClerq SC, Khatry SK, Shrestha SR, Pradhan EK, Tielsch JM, Pandey MR \& Sommer A (1991) Efficacy of vitamin A in reducing pre-school child mortality in Nepal. Lancet 338, 67-71.

World Health Organization (1995) World Health Report: Bridging the Gaps. Geneva: World Health Organization. World Health Organization (1997a) South East Asia Region Regional Health Report. New Delhi: World Health Organization South East Asia Region.

World Health Organization (1997b) Vitamin A Supplements: A Guide to their Use in the Treatment and Prevention of Vitamin A Deficiency and Xerophthalmia. Geneva: WHO.

World Health Organization (1998) World Health Report: Life in the 21st Century. A Vision for All. Geneva: World Health Organization.

Zumrawi FY, Dimond H \& Waterlow JC (1987) Effects of infection on growth in Sudanese children. Human Nutrition: Clinical Nutrition 41C, 453-461. 